NBSIR 76-1152

\title{
Report to AID on an NBS/AID Workshop on Standardization and Measurement Services
}

Edited by:

H. Steffen Peiser

Joan Cornish

Charles C. Raley

Office of International Relations

National Bureau of Standards

Washington, D.C. 20234

Held September 20 - October 3, 1975

Issued March 1977

The Workshop was conducted as a part of the program under the US/NBS Agency for International Development PASA TA (CE) 5-71.

Prepared for

Agency for International Development Department of State Washington, D.C. 20523 



\section{REPORT TO AID ON AN NBS/AID \\ WORKSHOP ON STANDARDIZATION \\ AND MEASUREMENT SERVICES}

\section{Edited by:}

H. Steffen Peiser

Joan Cornish

Charles C. Raley

Office of International Relations

National Bureau of Standards

Washington, D.C. 20234

Held September 20 - October 3, 1975

Issued March 1977

The Workshop was conducted as a part of the program under the

US/NBS/Agency for International Development PASA TA (CE) 5-71.

Prepared for

Agency for International Development

Department of State

Washington, D.C. 20523

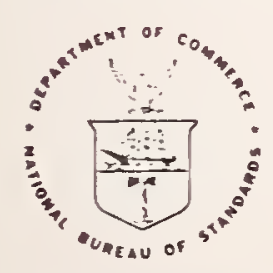

U.S. DEPARTMENT OF COMMERCE, Juanita M. Kreps, Secretary

Dr. Betsy Ancker-Johnson, Assistant Secretary for Science and Technology

NATIONAL BUREAU OF STANDARDS, Ernest Ambler, Acting Director 

The coordinated nrogram of the National Bureau of Standards, in support of the Agency for International Development, to assist industrializing countries and regions of the world with their goals in standardization, quality control, and other technical measurement problems, has included annual workshops in the U!.S.A. to show and illustrate how standardization and technical measurement services are provided to industry, government agencies, and the U.S. public. Thereas previous reports of these Norkshopst have described the character and the program elements in some detail, only a summary is here presented.

A small number of participants with mafor technical responsibilities in standardization or measurement services in their own countries are invited to spend two weeks in the U.S.A. The first week they remain in Washington. Subsequently, they tour some key centers elsewhere in the U.S.A. During that first week the major programs of NBS are described and so are those of other selected federal agencies with major functions in standardization and measurement services. Distinguished sneakers give after-dinner discourses of general but related interest. During the second week the Workshop participants visit selected private sector standards writing organizations, universities, and research institutions supporting development activities, industrial companies with strong quality control proorams, and test laboratories. The program is typically demanding and full. NT.S encourares participants to select much U.S. standards literature and standard reference materials to be sent to their home institutions for effective use in their own countries. During the Workshop each participant delivers a paper to the group on a topic connected with standards of metrology in his home country. Existins services, problems and opportunities are described and debated by the group. These papers are reproduced in this report without the discussion.

The following countries were represented in this year'g Workshop. An asterisk indicates countries taking part for the first time in this series:

Afghanistan*
Brazil
Chile
Colombia*
Dominican Republic*
Egypt*
Jordan*
Korea
Nicaragua*

† Workshops held April 23-28, 1972 (NBS Report 10 901); May 4-18, 1973 (NBSIR 73-275); íay 11-24, 1974, (NBSIR 74-550); November 3-16, 1974 (NBSIR 75-769) 
The U.S. National Conference of Standards Laboratories (NCSL) invited general representation from abroad for the first time to its annual Seminar held this year at NBS Boulder, Colorado. These circumstances provided a special opportunity for the NBS/AID Workshop to attend the major part of the iNCSL meeting.

During the first week, the evening discourses included a brief introduction to AID and its cooperation with NBS by Mr. John C. Fry, Deputy Director, Office of Science and Technology of the Technical Assistance Bureau; an outstanding portrayal of the U.S. Geological Survey by the Chief of its Office of International Geology, Dr. J. A. Reinemund; and a fascinating description of the formative stages of the Congressional Office of Technology Assessment, by its Deputy Director, Dr. D. V. De Simone, formerly an NBS employee, Director of the Metric Study, and former Chief of the NBS Office of Inventions and Innovations.

Luncheon presentations were given by a sample of sister agencies:

1) the Food and Drug Administration by Dr. F. L. Kauffman, Assistant Director for Manufacturing Practices;

2) the National Technical Information Service, Is. V. A. Dowd, Special Assistant to the Director for Promotion; and

3) the Consumer Product Safety Commission, Dr. G. C. Iichols, Special Assistant to the Chairman for International Affairs.

IVS is fortunate again to have received enthusiastic support of these agencies. Of great importance to the success of the Workshop were the receptions that were accorded to us at:

1) the Electrical Testing Laboratories, Inc.,

2) the American ivational Standards Institute, Inc.,

3) the Research Triangle Institute,

4) the Georgia Institute of Technology,

5) the Southwest Research Institute,

6) the International Business Machines Corporation,

7) the Burroughs Wellcome Company, and

8) the University of Texas at San Antonio. 
In addition, the American Society for Testing and Materials gave us a special program at NBS in order to save travel time for the Workshon participants.

The Workshop participants, by their own initiative suggested an evaluation questionnaire for participants to complete. These answers are condensed in Appendix I. Almost all participants gave us the benefit of their evaluations.

For the first time, participants contributed to the cost of their Forkshop attendance. NTS and AID are appreciative of this demonstration of interest. However, there is a deeper sense of rratitude that I personally vant to express. I am responsible for maliing the program so full and concentrated with so many diverse influences and tonics that attendance is a physical and mental hardship. I cannot expect senior officials to be able to spare more than two weeks from their posts. A less diversified workshop would fall short of fulfilling our isitors' expectations. My choice was to arrange a very crowded program.

The participants did understand. I thank them very much.

H. Steffen Peiser

Chief

office of International Relations 


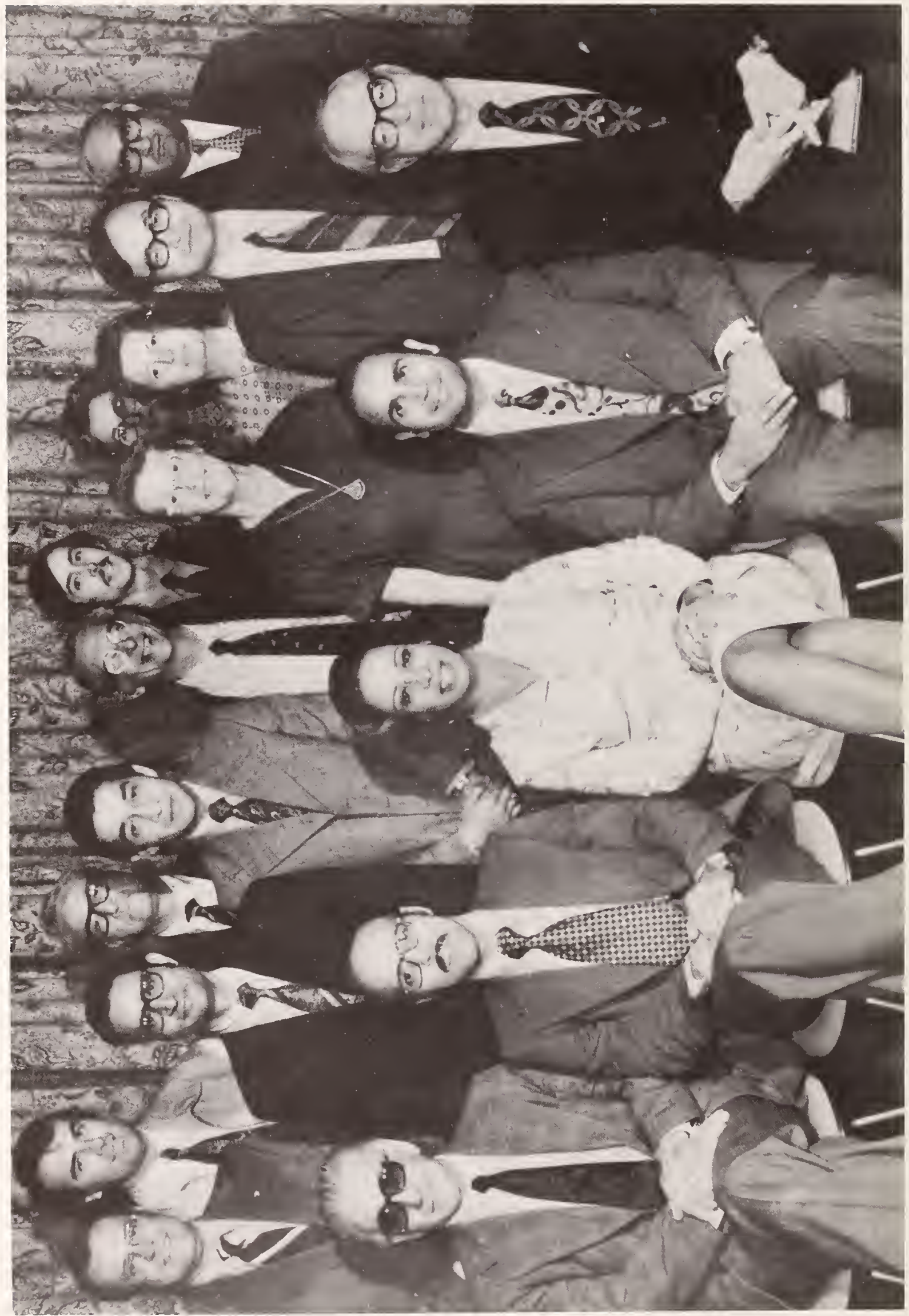




$$
\begin{gathered}
\text { NBS/AID WORKSHOP } \\
\text { on } \\
\text { STANDARDIZATION AND MEASUREMENT SERVICES } \\
\text { Group Photograph Taken at NBS Gaithersburg Laboratories }
\end{gathered}
$$

First Row, Left to Right:

Dr. Hugo Brangier M., Mr. Abder Rahman El-Keilani

Dr. Josefina Espaillat Duran, Mr. Taj Mohammad Yarmand,

Dr. Edward L. Brady $\dagger$

Back Row, Left to Right:

Mr. Charles B. Phucas, + Mr. Ricardo Florez, Dr. Anwar E1-Tawil,

Dr. Enrique Guerrero L., Mr. Jorge Enrique Barrios,

Mr. H. Steffen Peiser, + Mr. Charles C. Raley, $t$

Mrs. H. Steffen Pelser, Mrs. F. M. Bullman, T

Irs. E. Joanne Mejeur, $T$ Mr. Chong-ilin Lee, Mr. Sher Muhammad*

$(t)$ NBS

(*) Visitor from USAID, Is lamabad 
PREFACE, Mr. H. Steffen Peiser, Chief, Office of International Relations, National Bureau of Standards,

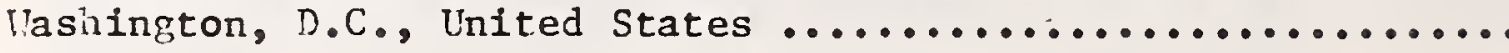

Photograph..................................... iv

Photograph identification......................... v

Program of Workshop.............................. 1

STANDARDIZATION IN AFGHANISTAN, Yr. Taj Mohammad Yarnand,

General Director, Norms and Standards Department, Ministry

of Vilnes and Industries, Kabul, Afghanistan................

THE STATE OF SAO PAULO PROGRAM FOR SCIENCE AND

TECHNOLOGY - PROCET (SCIENCE AIT TECHNOLOGY PROGRAM)

A BRIEF DESCRIPTION, Mr. Ricardo Florez, Architect,

Institute for Technological Research, Sao Paulo, Brazil.......

A NATIONAL CERTIFICATION SYSTEM FOR CHILE,

Dr. Hugo Brangier M., Executive Director, National

Institute of Standardization, Santiago, Chile..............

STANDARDIZATION II: COLOMBIA, Mr. Jorge Enrique Barrios, Chief, Chemistry Division, Colombian Institute of

Technical Standards, Bopota, Colombia....................

SECTION ON WEIGITS ANB MEASURFMFNTS,

Dr. Josefina Espaillat Duran, Under-Secretary of State

for Industry and Commerce, Head, Standardization and Ouality Control Department, Santo Domingo, Dominican

Republic.

SOME ASPECTS OF STANDARDIZATIOIN AID MEASITREIENT IN EGYPT, Dr. Anwar F1-Tawil, Chief, Industrial "etrology Division, Egyptian Organization for Standardization,

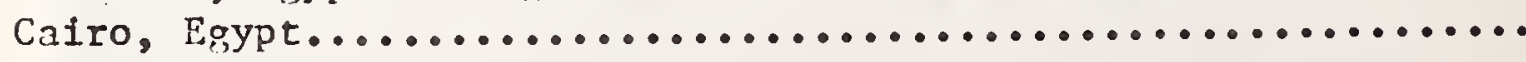


STANDARDIZATION IN JORDAN, Mr. Abder Rahman El-Kellani, Head, Weights and Measurement Section, Directorate of Standards and Metrology, Ministry of Industry and Trade, Amman, Jordan.................................... 64

SOME NISEI PROJECTS FOR STRENGTHENING ITAION-TIDE

TECHNICAL SUPPORT CAPABILITIES OF KOREA'S NATIONAL

RESEARCII A TESTING ORGANIZATIONS, Mr. Thong Min Lee,

Chief, Planning Division, National Industrial Standards

Research Institute, Seoul, Republic of Korea............. 68

VEIGIITS AND :EASURES IN NICARAGUA, Dr. Enrique Guerrero L.,

Chief, Food and Quality Control Division, Ministry of

economy, Industry, and Commerce, Managua, Nicaragua.......... 86

APPENDIX I WORKSHOP EVALUATION STATEMENTS............... 89

APPENDIX II WORKSHOP PARTICIPANTS AND BIOGRAPHICAL DATA ..... 99

vii 

National Bureau of Standards Agency for International Development

Workshop on Standardization and Measurement Services

September 19, Friday

PM

September 20 , Saturday

12:00 Noon

PM

September 21, Sunday

$$
\text { AMI }
$$

Pín

5:00 PM

September 22, Monday

$$
\begin{aligned}
& 9: 00 \mathrm{~A}:- \\
& 9: 15 \mathrm{AM} \\
& 9: 15 \mathrm{AM}- \\
& 9: 45 \mathrm{AM} \\
& 9: 45 \mathrm{AM}- \\
& 10: 15 \mathrm{AM} \\
& 10: 15 \mathrm{AM}- \\
& 10: 30 \mathrm{AM} \\
& 10: 30 \mathrm{AM}- \\
& 12: 00 \mathrm{NOOn}
\end{aligned}
$$

Park Central Hotel

Washington, D.C.

Reception and Lunch

Hosts: Dr. E. L. Brady, Associate Director for Information Programs;

Mr. H. S. Peiser, Chief,

Office of International Relations

Free

Free

Holiday Inn

Gaithersburg, in

Dinner - USAID Programs Presentation,

Mr. J. C. Fry, Deputy Director, office of Science and Technology

Greetings, Dr. E. Ambler

Acting Director, NBS

iNBS Overview, Dr. E. L. Brady

Workshop Introduction, Mr. H.S. Pelser

Break

Plenary Session - Speeches by participants on programs, problems and opportunities in standards and measurement in home countries 


12:00 iNoon -
2:00 PM
2:00 PM -
3:00 PM
3:00 PM -
3:15 PM
3:15 PM -
4:00 PM
4:00 PM -
5:00 PM
6:30 PM

September 23, Tuesday

9:00 AM -

10:15 AM

$10: 15$ A.1 -

$10: 30$ AM

$10: 30 \mathrm{AM}-$

12:00 Noon

$\begin{aligned} & 12: 00 \text { Noon - } \\ & \text { 2:00 PM }\end{aligned}$

2:00 PM -

3:15 PM

3:15 PM -

3:30 PM

3:30 PM -

5:00 PM

$6: 30$ PM

September 24, Wednesday

9:00 AM

$10: 15$ Ais
Lunch - Presentation, Mr. H. S. Peiser

The International Activities of NBS

Metric Information Office, Mr. J. V. Odom, Chief

Break

Standards Information and Analysis, Dr. L. Eicher, Chief

Office of Weights and Measures, Mr. H. F. Wollin, Chief

Dinner - Presentation by Dr. J.A. Reinemund, Chief, Office of International Geology, U.S. Geological Survey

American Society for Testing and Materials, Mr. S. F. Etris, Special Assistant to Managing Director of National Affairs

Break

Tour of iNBS Campus

Lunch - Food and Drug Administration Presentation, Dr. F. L. Kauffman, Assistant Director for Manufacturing Practices

Institute for Basic Standards, Dr. H. A. Fowler, Scientific Assistant

Break

Institute for Materials Research, Mr. G. A. Uriano, Scientific Assistant Dinner

Institute for Applied Technology, Dr. N. F. Somes, Scientific Assistant 


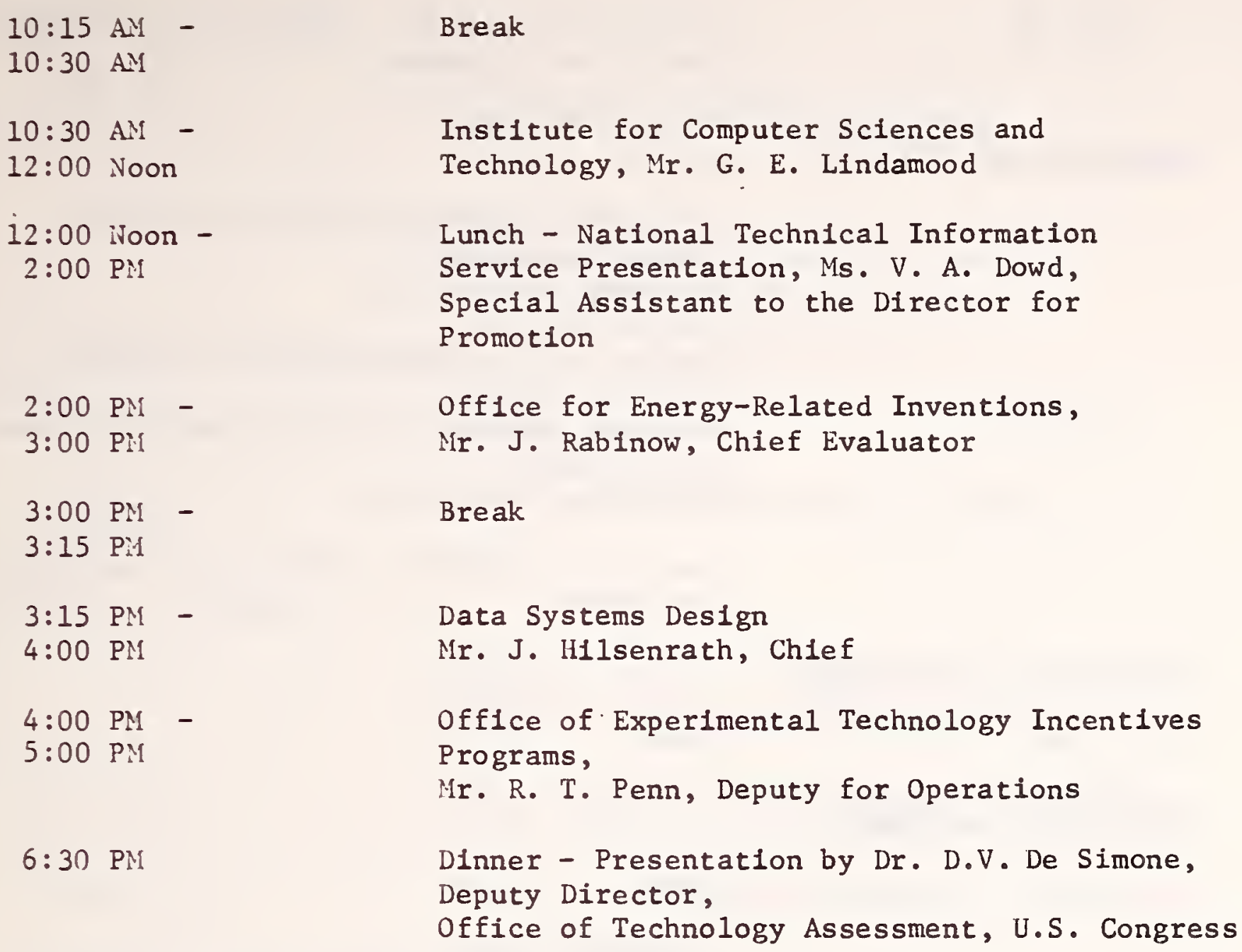

\section{Break}

Institute for Computer Sciences and Technology, Mr. G. E. Lindamood

Lunch - National Technical Information Service Presentation, Ms. V. A. Dowd, Special Assistant to the Director for Promotion

Office for Energy-Related Inventions, Mir. J. Rabinow, Chief Evaluator

Break

Data Systems Design

Mr. J. Hilsenrath, Chief

Office of Experimental Technology Incentives Programs, Mr. R. T. Penn, Deputy for Operations

Dinner - Presentation by Dr. D.V. De Simone, Deputy Director, Office of Technology Assessment, U.S. Congress

Office of International Standards,

Mr. C. B. Phucas, Deputy to Chlef;

Mr. D. E. Edgerly, Special Assistant

(Break at 10:15 AM)

Free

Group Photograph

Lunch - Consumer Product Safety Commission Presentation, Dr. G. C. Nichols, Special Assistant to the Chairman for International Affalrs

Center for Building Technology, Mr. N. J. Raufaste, Assistant to the Director for Program Planning 
3:15 PM -

4:00 PM

September 26, Friday

$9: 30 \mathrm{AM}$

2:00 PiI

September 27, Saturday

AM - PM

September 28 , Sunday

AM

Free

Governor's Inn

Research Triangle Park, N.C.

September 29, Monday

Air - PM

Farewell Reception

Host: Dr. E. Ambler

2 East End Avenue

New York, N.Y. 10021 1430 Broadway

New York, N.Y. 10018 Operations

Free

Research Triangle Institute
Electrical Testing Laboratories, Inc.

Hosts: Mr. D. Schrum and Mr. C. Hyer

American National Standards Institute, Inc.

Host: ifr. Pisclotta, Director of Technical

P.O. Box 12194

Research Triangle Park, N.C. 27709

Hosts: Mr. G. R. Herbert, President;

Dr. T. Wooten, Executive Assistant

to the President

International Business Machines Corporation Burroughs Wellcome Company

Atlanta Townehouse

Atlanta, Georgia 
September 30 , Tuesday

9:00 AY

7:00 PM -

$9: 00$ P:1

October 1, Wednesday
Engineering Experiment Station Georgia Institute of Technology Atlanta, Georgia 30332

Hosts: Prof. R. W. Hammond, Chief, Industrial Development Division and Prof. Kenneth S. Stephens, Head Adaptive Technology Group

Harvest House Boulder, Colorado

Conference Registration and Reception
National Bureau of Standards Boulder, Colorado 80302

NBS - Boulder Overview, îr.J. L. Dalke, Chief, Office of Measurement Services

National Conference of Standards Laboratories Awards Ceremony

National Conference of Standards Laboratorles

Menger Hotel

San Antonio, Texas

October 3, Friday

$9: 00 \mathrm{ANI}$

Southwest Research Institute

8500 Culebra Road

P.O. Drawer 28510

San Antonio, Texas 78284

Hosts: Dr. D. Black, Director, Special

Programs; Mr. H. I. Hoffman, Manager, Central Proposal office

also:

University of Texas at San Antonio

Conclusion 


\section{Mr. Taj Mohammad Yarmand}

General Director

Norms and Standards Department

Ministry of Mines and Industrles

Kabul, Afghanistan

Afghanistan traces its history back over 5,000 years. In the past it was a great center of civilization. In 1919, Afghanistan received its independence after the third Anglo-Afghan War. Presently Amanullah Chan strives for modernization of the country. In July 1973, the country reached 1 ts zenith of progress in the establishment of the Republic of Afghanistan by a national hero, Mohammad Dawood.

The economy of Afghanistan is based on agriculture and small scale industry. Major products are: fresh and dried fruits, karakul (a soft wool from an Aslan breed of sheep), handwoven carpets and rugs, cotton, furs and a large variety of handicrafts. Afghanistan has many kinds of minerals, which are mined, natural gas, and other resources. More than $80 \%$ of the people, however, work in agriculture and livestock. Industry in Afghanistan is now developing alongside agriculture. Many consumer products, for example, cars and many raw materials and metals, are imported into Afghanistan. The country exports frult, minerals and handicrafts. Afghanistan has been striving to exploit all the underground and above ground natural resources in order to Improve the quality of its export and domestic products.

Until 1973, Afghanistan did not have a National Bureau of Standards which could concern itself with the study and preparation of national standards. In September 1973, under the direction of the Government, a new department of "Norms and Standards" was established. It is a part of the Ministry of Mines and Industrles and has the following alms and functions:

\section{Aims}

1. To Improve the effectiveness and capability

of national production in various economic sectors, to promote the quality of production and to secure the consistency of better production.

2. To ensure a proper relation between the quality of production and the economic and social development of the country. 
3. To secure the required conditions and facilities

to promote the exportation of goods that are acceptable

for international markets.

4. To secure the required facilities to limit the

number and quality of imports.

5. To improve the conditions and provide economic incentives

for organizations determining the quality of their products.

6. To create and promote progessive and specified methods

for designing and processing of products.

7. To obtain a maximum but reasonable advantage from products and resources, and to minimize the expenditure of human and material resources.

8. To create sultable sanitary working conditions and to take safety measures for varlous speciallzed tasks.

\section{Functions}

1. To plan and set up national standards for all products and measuring methods, and their operation and control.

2. To study and apply international standards, according to the economic, soctal, cultural and regional conditions of Afghanistan.

3. To publish and distribute approved standards, and apply them in industries, agriculture and the other economic fields.

4. To cooperate with industrial and scientific organizations, wth the public and private sectors, and to consider their proposals for developing national standards and for preparing standards for all traditional handicrafts according to modern progressive methods.

5. To carry out different scientific, technical and economic investigations and research in order to complle inventorles of avallable technical qualifications and standards.

6. To create cooperative relations with international and regional standard organizations and to apply recommendations and experience of international organizations. 
7. To strengthen the cooperative relationships with the universities and with all the scientific and educational institutes of the country.

8. To publish and issue publications on all aspects of standardization.

9. To establish archives of national and International standards and to provide information and facilities for concerned individuals, producers, and institutes.

10. To establish and maintain laboratories for the purpose of scientific and technical investigations in the field of standardization and the control of the quality of product.

11. To train vocational and administrative personnel, by organizing long and short term service courses as well as seminars and conferences. Personnel would also be sent to friendly countries for increasing vocational and administrative knowledge of standardization of the Bureau.

12. To initiate cooperation with other Ministries and Institutes, for the purpose of ensuring quality of local products, by applying national standards and seeking specified characteristics in collaboration with producers, importers and exporters.

13. To give technical and scientific guidance to producers, importers and exporters on the specifications, standards and quality of products.

14. To compare the properties of samples of products with the relevant standards and to issue the privilege of the use of the standard symbol, according to the applicable regulations.

15. To harmonize measurements in Afghanistan, publicize the international metric system and units and to adjust measuring instruments according to regulations.

At present 22 graduate personnel are working in the Norms and Standards Department, and by projections 45 will soon be employed. 
In accordance with existing programs of the Norms and Standards Department of the Ministry of Mines and Industries, national standards for textiles, cement, soap, minerals for export and vegetables w111 all be developed. The Norms and Standards Department has prepared drafts of the standards for 16 items of cotton and rayon textiles. They are the key in determining quality and specifications of quality for these textile products.

In. Afghanistan, norms and standards are a new experience and their impact from the scientific and economic point of view is not yet fully felt. As a result of surveys and studies carried out by industrial enterprises, it has been established that as a result of a lack of norms and standards and a lack of laboratories for testing the quality of products, low quality goods are produced from high quality raw materials. This state of affairs not only poses an economic loss to the producers, it also damages national economy.

In the past, various kinds of goods vere imported without taking into consideration the quality, climatic conditions and economic value of the goods. In other words, the principles of standardization were not taken into consideration when importing goods.

Standardization makes coordination easier between local traders, producers, exporters and importers. It provides a boost to the economic development of the country. Multi-directional roles of standardization and metrology affects every walk of economic IIfe of the country.

Our Department of Norms and Standards hopes to establish contacts with all the ministries in the country, Kabul University, municipal, governmental and private enterprises, ISO (International Organization for Standardization), IEC (International Electrotechnical Commission) and other national bodies for standardization and metrology. The Bureau will cooperate and make every endeavor to establish laboratories where different domestic consumer goods could be analyzed from the point of view of quality and their feasibility for production in Afghanistan. Similarly, the consumer goods being imported into the country will also be tested and analyzed in these laboratories.

The Afghan Norms and Standards Department (in cooperation with the Education Ministry and Kabul University) hopes to popularize these subjects of standardization, metrology and quality control. At present these subjects of specialization are not represented. The Department will introduce basic principles of standardization, metrology and quality control as a subject in professional schools as well as at university level. The course w1ll be introduced for students in the final year of the school. 
The Afghan Norms and Standards Department, through proper channels, has applied for membership in ISO and IF.C. We hope to cooperate with other national organizations for standardization in different countries because practice shows that extension of international trade and improving quality of products partly depends on cooperation with other national bodies.

At present we have contact with some organizations in other countries. I hope that my visit to the National Bureau of Standards in the United States will bring benefits to us for developing our activities in the future in the field of standardization and metrology and that we will have good contacts in this important field. 


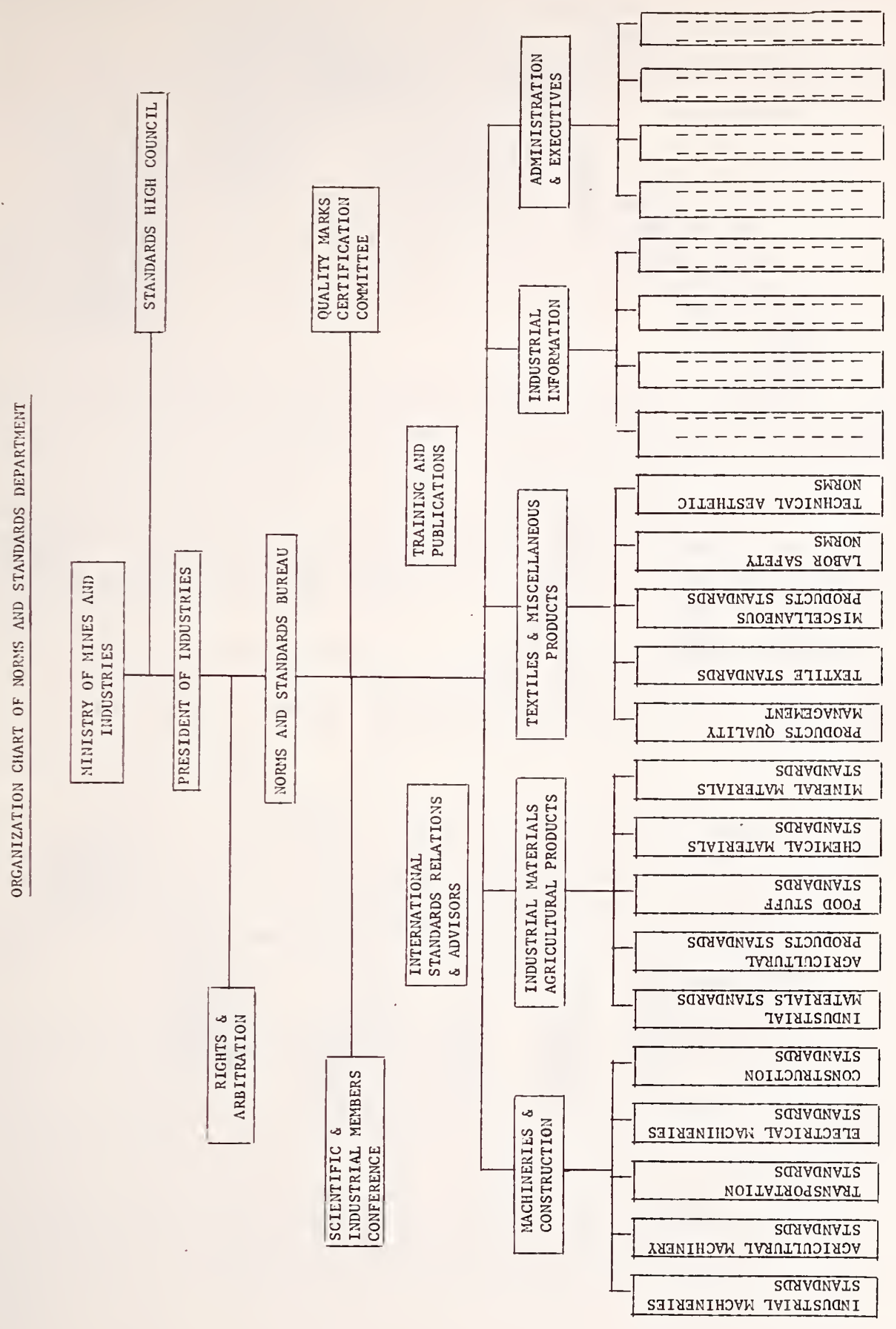




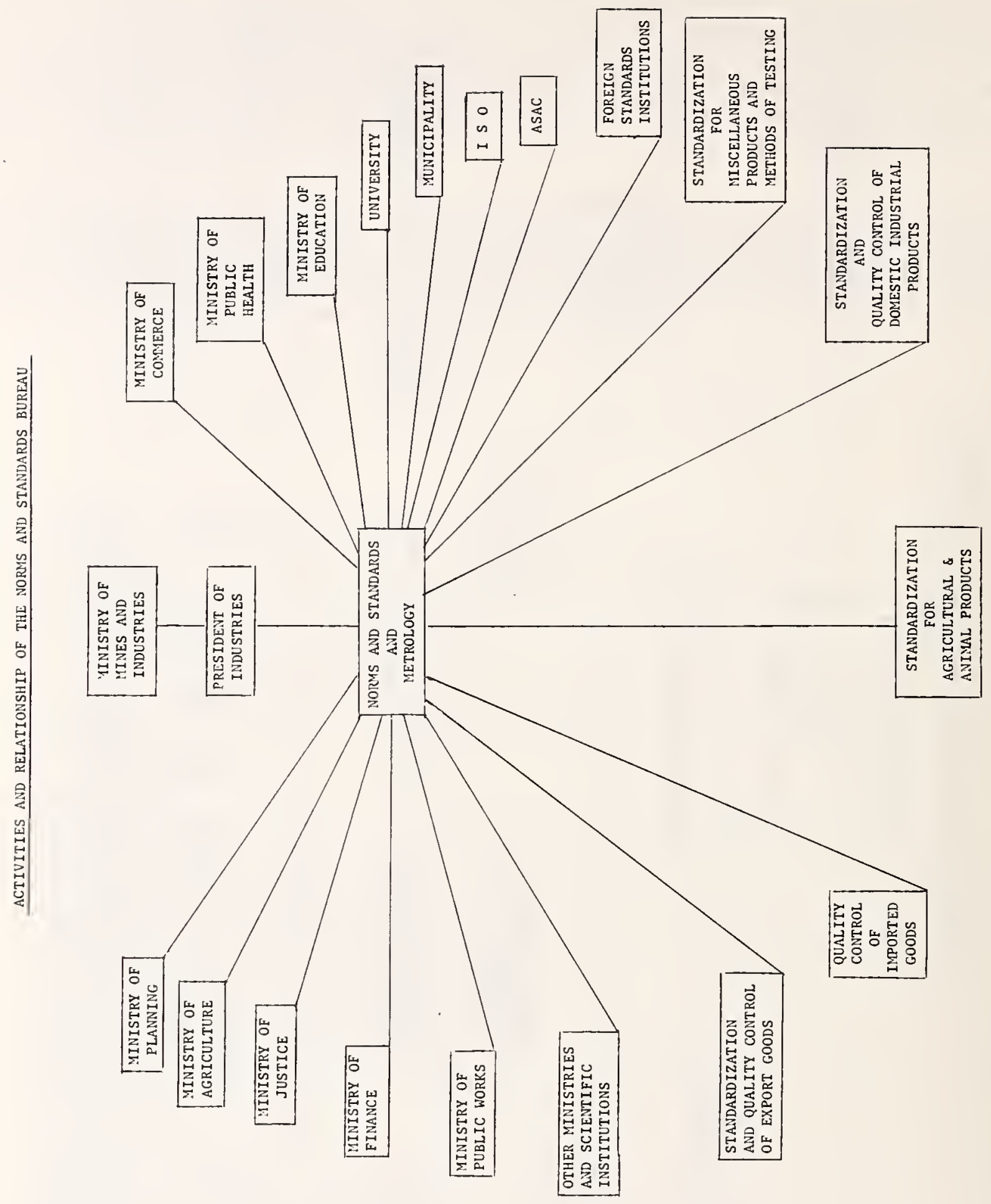


TTIE STATE OF SAO PAULO PROGRAM FOR SCIENCE AND TECHTOLOGY - PROCET (PROGRAIA CIENCIA E TECIOLOGIA)

A BPIEF DESCRIPTION

\section{Picardo Florez} Architect

Technological Research Institute

Sao Paulo, Brazil

\section{INTRODICTION}

It is the purpose of this Report to describe the main goals of the State of Sao Paulo Government in the overall effort to imrrove science and technology, and their assessment and utilization by the Brazilian industry. These goals are clearly stated today in many Governement proprams being implemented, the most innortant of them beinr the Science and Technology Program, Procit (Programa Ciencia e Tecnologia), under the Sao Paulo State Council for Techrology, CeT (Conselno Estadual de Tecnoloria). The author of this Perort has used frecly available literature describinr this and related prorrams.

The U.S. Arency for International Development (USAIn) is providins the State of Sao Paulo, through CE? w th one third of the operational

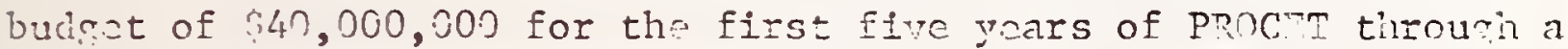
lon under the spirit of the "Mliince for Progress" and tio Forein issistance Act of 1951 .

PROCFT. involves the development of a systen by whic: Government resource allocations to science an technolory are, to the extent possible, based unon the needs and onnortunities of the marletplace. That systen is built on the existing infrastructure. The roles of the existing institutes, governmental and private, are extremely important.

The Technological Pesaarch Institute for the State of Sao Paulo, IPT (Instituto de Pesquisas Tecnoloricas), is the bigrest Government research institute in Sao Paulo, and in many aspects the largest also in Brazil. This is cue to the fact that $65 \%$ of the Brazilian rross national product (GIP) cones from Sao Paulo State, and a bir portion of that from the city of Sao Paulo itself, where the main Brazilian industrial park, which IPT set out to serve, is located. IP''s activities under PROCET will be describar, with erphasis on the international collaborative prograns that, even if not fully addressing, all the program areas, play the most imnortant role in nany of then. 


\section{CET HISTORY}

CET was created by a State of Sao Paulo Decree (49.066) on Decenber 14, 1967, under the Secretary for Econorics and Planning, and so operated until the end of 1974 when it vas transferred as an iperational agency to the Secretary for Science, Culture, and Technology.

CET ROLES

The principal roles of CFT are to:

1. propose the technolorical policies for the industrial, agricultural, biological, and chanical sectors for the State of Sao Paulo;

2. coordinate the research activities and planning for State Government agencies, public enterprises, or otkers where the State Government is a major shareholier;

3. design technological research incentive programs for the public and private sectors;

4. design educational incentive prograns for scientists, researchers, and techicians;

5. supervise the allocation of funds for private technological research and evaluate the results;

6. assess the evolution of Sao Panlo State in science and technology, counseling the Government when necessary;

7. evaluate specific situations and problens concerning the State technological and technical development;

3. collaborate with other state or federal organizations in national technological development programs; and to

9. inplement scientific information exchange between national and international institutions.

CET GOALS AND ORJECTIVES

The principal goals and objectives of CET are to:

1. include techmology in the expansion process of the 
State and national economy;

2. enhance Brazil's technological participation in the international economical scene; and to

3. pronote national research and devclopment activities using international standards as reference.

CET OPERATIONAL CRITCRIA FOR EVALUATIOH OF ITS PROGRA:S

The above items cover the overall ideal goals and objectives. In order to operate and evaluate the work being done, the following criteria are to be considered:

1. Cost reductions in industrial products.

2. Increase in marketability of Brazilian products abroad.

3. Increase in utilization of domestic natural resources.

4. Improvement of the status of researchers in order to obtain a more stable and productive team.

5. Optinization of the utilization of financial resources for research in order to avoid overlapning of humain effort, and human and material resource utilization.

6. Triancement of innovation and all other ways and means to achieve foreign technology adaptation, when feasible, in order to reduce gradually the need for inport lnow-how.

Author's note: Item 6 may correctly describe present Government policy. Ilowever, in the author's personal opinion this policy eventually should be modified to one where the imnorted know-how is balanced by the benefits from exported new technology.

\section{CET ACTIVITIES - EIPECTED OUTPUTS}

At the Government level, CET activities are cxnected to stinulate the development, transfer, and utilization of the best technolony avallable in order to enhance social development for the State of Sao Paulo and for Brazil, and to chanrel resources to desired goals.

For the benefit of research institutes, CIT activitics are expected to build up institute potentials in coping with their maricet needs. 
For producers, CET hopes to provide the basis for improvement of the capability to select adequate technology.

\section{CET ACTIVITIES - STRATEGY}

Starting in August 1971, and under the guidance of the first liational Social and Economical Development Plan - P.N.D. (Plano Nacional de Desenvolvimento Economico e Social 1972/1974), CEr has applied its own operational procedures, following other countries' experiences with science and technology and paying due regard to present conditions and opportunities in the State of Sao Paulo.

Historically, Brazil, and mainly the State of Sao Paulo, went through a major upsurge in industrial activity during the second World War, when import substitution became an important requirement. Even before that war, new technologies vere badly needed, but the industrial establishments preferred to import then. The very important step towards self-reliant industrialization took place vitiout adequately benefiting from the efforts of all the universities and research institutes for development of new techrologies or recognizing the need to adapt the existing technologies to Brazil's conditions. For the 25 years that followed the import substitution policy, this nerlect continued. The result today is a lack of industrial development coordination and effectiveness at the State level. CET now has operational mechanisms, lookinr, for better results, in full conformity with Brazilian federal plans. In the followine pararraphs, the author describes in turn the major mutually supportive, but basically independent, programs. It is well to ouserve that there is some overlap in activities between these prorrams. In this important respect, CET policies differ from tilose of some other industrializing economies which favor stricter compartmentalization.

A survey is carried out of all research institute activities and publications to be used as references by potential customers. The first volume listing all such services and activities was published in 1972, and since then, periodically, twice a year.

Arreement with Rescarch and Development Financial Organizations FIIJP (Financiadora de Estarlos e Projectos S/A)

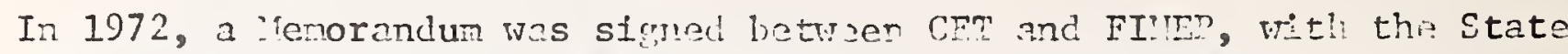
of Sao Paulo Government as intemalicry, allocating $\$ 15,000,000$ for rescarch and development for the next 3 years. As a rosult, the "Technological Development Program", PDT (Programa de Desenvolvimento Tecnologico), was implemented. This program was designed to provide financial support for research expansion in the State of Sao Paulo for national firns, private or public, in any field of activity, 
located witivin the State, for Government institutions, state or municipal, and also universities or private research grouns.

The allocation of funds had to follow the following nriority order:

1. Research for industries needing much technolory.

2. Research to strenththen healthy competition between national industries.

3. Research to increase national technological and nanagerial capabilities.

4. Lise of Sao Paulo techrical capabilities to the benefit of other regions of Brazil.

5. Agro-industry researci.

6. : iarketing research for export and domestic trade expansion.

7. Joint research with Federal institutions.

3. Research and implementation of standards and quality control.

\section{Technology Dissemination Prorram (Difusao de Tecnologia)}

In a joint effort with the "Technology Information Program" (sce above), the Iechnology issemination Program is responsible for visits to industries and organizing meetings and scrinars to bring topether industrles and research institutions.

Science and Technolory Program - P'OCL:

PROCET is being inplemented by CIT in Sa Paulo to expand the use of technologlcal services by the industrial and agro-industrial communities and, with the State of Sao Paulo research institutions, to strengthen then and to improve specific areas of know-how to achicve national excellence.

State Scientific and Techiolozical Develorment Fumd - FUiCET (Fundo Estadual de Desenvolvimento Cientilico e Tecrolorico)

FU:ICET was instituted by Decree I:o. 1276 on March 14, 1973, to f1nance:

1. research and projects in State priority areas;

2. know-how transfer programs between universities, 
research institutes, and industry;

3. programs for build-up of human resources;

4. scientific and technological evaluation prorrams;

5. development of standards;

6. laboratory construction and equipment purchases for quality control; and

7. joint scientific and technological programs with other states.

State Sclentific and Technological Information Systems - SFICT (S1stema Estadual de Informagoes Cientificas e fecnologicas)

SEICT was started in 1971 and is basically a computerizor information networl: 1inked to the ilational Information Systen - SiICT (Sistema Tacional de Informacao Cientifica e mecnologica) and, directly or indirectly, with international systems.

\section{THE SCIENCE AND TECHNOLOGY PROGRAY - PROCET}

Desicned and managed by CEI, ProCE: is composed of a set of programs and products in the areas of tecinological and scientific policy, technology marketing, rescarch managenent, technolorical information, metallurny, quality control certification, and foor techrolocy. It is being implemented in Sao Paulo undor the reneral planning cfforts and activities with the objective of achievinc a continuing $9 \%$ a year economic srowth and related social, technical, and economic development.

The preliminary research done by CET with respect to international experience in the field of technolonical transier promrams showed surprising facts. Even though many countries have achieved hioh specific technological develonment, throrles on scientific and technolorical policy are scarce. In 1966, In a meetinn that tool: place in Czechoslovalia sponsored by yrrsCo, it was recommended that each country should establish its own specific science and technology programs, commensurate to their importance and to the lacl: of existing international coordination. The arount of information concerning national science and technology policies, attitudes, and mechanisias the world over remains small. Just a few scientific institutions, such as the ilassachusetts Institute of Tcchnology, Northwestern University, Susser Iniversity (Fnrlant), U.TSCO, and a few others, have given priority to science and technology policy studies. 
The general approach in the world is to have scientific documents and information available in a passive way or to have technology created and transferred to industries by private institutions, without any regard to prior work and to the general social and economic policies of the comnunity.

With nowhere to go for general assistance, CET decilied to keep as informed as possible on programs in other countries and at the same time to start working in specific areas with different institutions in order to achieve an ideal balance in serving the needs of the State Government. With this in mind, PROCET has been instituted. It is made up of a set of programs, divided into projects, erecuter by Brazilian researcil institutions assisted by we11-known institutions from abroad, each one specialized in specific technological areas, under the supervision of CET.

\section{PROCET PROGRAI: AREAS}

The present set of programs with its Brazilian institution in charge and foreign assistant counterpart follows:

1. Scientific and technological policy -

FCAV - University Foundation naned after Carlos Alberto Vanzolini (Fundacao Carlos Alberto Vanzolini)

III - Yassachusetts Institute of Technology

2. Research Nanagement -

FUIDAD - Nesearch Foundation for the Administration of the Faculty of Sao Paulo university

(Fundo de Pesquisa do Instituto de Administracao da Fea)

Vanderbilt University

3. Techrology iliarket -

FCAV - Fundacao Carlos Alberto Vanzolini

SRI - Stanford Research Institute

4. Technological Information -

CET (without unique counterpart institution)

5. Hetallurgy -

IPT - Instituto de Pesquisas Tecnologicas

DRI - Denver Research Institute

6. Ruality Assurance -

IPT - Instituto de Pesquisas Tecnologicas

iiBS - National Bureau of Standards 
7. Food Technology -

ITAL - Institute for Food Technology

(Instituto de Tecnologia de Alimentos)

CODOT - Consortium for the Development of Technology, University of Phode Island

\section{PROCET STRATEGY}

The above listed prograns constitute two main progran areas:

1. Software -

Sclentific and teclnolorical policy,

Research managerent,

Technology narket, and

Technology information.

2. Ilardware -

"etallurgy,

Quality assurance, and

rood technology.

The so-called "software" programs silould provide ways and means to survey, develop, institute, and implement science and technology polictes. The second program group, or the so-called "hardvare", concerns the technology itself and constitutes a small experiment in transfer and developnent. Projects in that group, therefore, are called "Demonstration Projects". The balance betveen both groups is the key on which the success of PrOCEI will depend. Generally, it takes a long tine to achieve institutional changes and long-range goals. Demonstration projects, however, provide short-term results (up to 3 years), and allow the management team to check such factors as cost effectiveness, project tining, technology transfer, managerial expertise available, and marketing potentials. The representatives of the Brazillan industry voluntarily participating in the program will receive the results of the demonstration projects. The companies should benefit by seeing imports reduced, exports expanded, and costs reduced for the internal market. The demonstration projects have been selected to serve basic sectors of the Brazilian economy, such as metallurgy and food processing. One is basic for industrial production and the other for actual consumption. There are also extensive programs each covering, a broad range such as quality assurance, chemical analysis, and collaborative reference programs to building research, and food technology, reaching, a large number of economic sectors.

PROCET, nonetheless, is highly flexible when it comes to including or excluding new projects due to changes in the political national or 
international scene or to implementing the evaluation of the results being achieved. It is a PPOCET policy that even partial results from each project are to be used when possible without waiting for a final answer that may take a long time to be known. The program life span of 5 years seems to be reasnnable for good planning, management, and adjustment of policies after evaluations. It is important to give even demonstration projects time to maturo and to observe the effects of management and policy decisions, that could not be adequately observed in shorter periods but that are most important to the aims of PROCET.

PROGRAIIS UNDER PROCET - GOALS AIN OBJECTIVES

PROCET Program on Science and Technology Policy

1. Evaluate Government programs and industrial practices as to their effectiveness in order to promote research for new and better utilization of the available technologies.

2. Evaluate the possible use of new programs.

3. Propose alternative policies in order to pronote technology implementation by the Sao Paulo industry.

4. Disseminatc the Sao Paulo experience to the other Brazilian states.

PROCET Program on Research Yanagement

1. Develop CET present and future administrative systems and organizational structure.

2. Contribute to the increase of the effectiveness of State research institutes.

3. Aralyze and Identify the critical elements for a more dynamic transfer of adequate and needed technology to medium and srall companies.

4. Consolidate the faculty for institute administration of the University of Sao Paulo - FEA - USP, so that it w111 be able to carry on the administrative tasks listed above even after PROCET activities end.

PROCET Progran on Technology Marketing

1. Evaluate the State research institutes' capability to 
propose and promote new technology for the public and private sector.

2. Sample public and private sector administrative attitudes toward technology development.

3. Study and select the most feasible irdustrial and governmental sectors for pilot programs for marketing.

4. Develop criteria for marketing science and technology programs.

PROCET Program on Technological Information

1. Generate the State system for scientific and technological information - SEICT.

2. Establish pilot "Information terminals" in a group of institutes.

3. Achieve a uniform, homogeneous and integrated scientific and technological information system.

PROCET Program on ?etallurgy

1. Increase IPT/industry interaction in order to increase industrial output and export capability.

2. Develop industrial trouble-shooting capabilities at IPT.

3. Increase managerial capabilities of the Metallurgy Division of IPT.

PROCET Program on Quality Assurance

1. Improve the quality of laboratory measurement techniques.

2. Establish inter-laboratorial reference programs.

3. Produce and distribute standard reference materials.

4. Experiment with measurement assurance programs.

5. Establish laboratory accreditation programs. 


\section{PROCET Program in Food Technolooy}

1. Improve research methodologies.

2. Optimize the ongoing research programs in order to have better and higher output from the existing facilities and personnel.

3. Transfer quickly to industry all final research outputs.

4. Promote research for new and better products in order to minimize Brazil's dependence on foreinn food and food processing technology and improve Brazil's position in the international market.

5. Promote research for lower cost of high nutrition products.

PROCET :IATAGEITNT

The above-described highly complex PROCET set of programs is being managed by CI.T. They are individual programs within a program (PROCET). The terminology of programs at two levels misht seen confusing for newcomers to the system. There is a PROCET general manager, seven program supervisors, one for each program, and nine project managers, a number of foreirn resident consultants working, full-time in Brazil, one or more for each program, at the same level as the program supervisors, and a number of Brazilian and foreion specialists working in Brazil, participating in training programs in Brazil or abroad, and foreign specialists coordinating special sectors for further development by the Brazilian team in Brazil or abroad. The PROCET operational structure has gone through many modifications and improvements during the first operational years and is to be further modified as needed.

\section{RUALITY ASSURANCE PROGRAM}

The author will now reproduce the outline of one of the PROCET programs, namely the Quality Assurance Program for which the National Bureau of Standards is the counterpart institute in the U.S.A. The 1973 Statement on the Standards Situation in Brazil is Annex 1. The Memorandum of linderstanding under which IPT and NBS cooperate is reproduced in Annex 2. The Report of the Evaluation Panel of the NBS/IPT Collaborative Program Between the Instituto de Pesquisas Tecnologicas and the iJational Bureau of Standards - First Annual Review, June 1975, is Annex 3. 
An increase in the average level of quality of manufactured products with reduced production costs and overall expenditures in quality control.

:leasures of goal achievement

1 - An increased participation of Brazilian manufactured products in the international market.

2 - Brazilian manufactured products becoming competitive on a quality basis.

3 - Decreasing necessity of fiscal protection for Brazilian manufactured products in the internal market.

4 - Decreasing expenditures in quality control of raw materials and semi-manufactured goods.

5 - Decreasing deviation and rejection of product in industry.

6 - Increasing interest in a national standardization syster.

Assumptions for achieving goal targets

1 - Introduction by the State Government of incentives and support to industry to improve its quality control systems and to participate in a standardization program.

2 - Export support for the elaboration of a detalled program.

3 - Support by the State Government for engaging and training personnel.

4 - Existence of an efficient information service and campaign for dissemination of technical explanations.

5 - Support for the target to be achieved in progressive stages, each defined in one or more specific projects.

PROGRAM PURPOSE OF NUALITY ASSURAITCE

1 - To define, with the State authorities, the imnediate 
action of fovernment institutions such as IPT, ITAL, IE, etc., as reference laboratories in the areas of manufactured products for export and for the State Government purchase agencies.

2 - To prepare a long range plan and schedule for the establishment of reference laboratories.

3 - To implement this plan.

Conditions that will indicate purpose has been achieved

1 - Manufactured products for export receiving a certification marking.

2 - State Government purchase agencies utilizing standards suitable for their particular requirements.

3 - Industries being approved as regular suppliers of specific items for the State Government.

4 - A detailed plan approved by the State authorities and the technological research institutes involved for the establishment of reference laboratories.

5 - Funds avallable for the implementation of this plan.

6 - Elaboration, acquisition, maintenance and utilization of reference standards conveniently checked with international reference standards.

7 - Performance of accurate and reproducible testiné programs of manufactured products of different industrial sectors.

8 - know-how transfer for the establishment and improvement of industrial and private testing laboratories.

9 - Active participation in national standards comittees.

10- Development of testing and research programs for the establishment of standards.

11- Introduction and improvement of standardization system at companies' level.

12- Expert support for the establishment or improvement 
of quality control systems in industry.

13- Certification markings for production lines of different industrial sectors.

14- Training of personnel for standardization, testing and quality control.

15- Topics for research and development projects.

Assumptions for achieving purpose

1 - Introduction by the State Government of incentives and support to industry in improving its quality control systems and participating in a standardization program.

2 - Task group appointed by the different research institutes involved.

3 - Expert support for the definition of the immediate action and long-range planning.

4 - Close contact with and support by the State authorities.

OUTPUTS OF OIJALITY ASSURANCE PROGRAM

1 - Certification markings given to exported manufactured products of priority sectors.

2 - Standards prepared for the State Government purchase agencies.

3 - Industries approved as regular suppliers of specific iters.

4 - Detailed plan for the establishment of reference laboratorles.

5 - Secondary reference standards produced.

6 - Testing programs of manufactured products of different industrial sectors performed.

7 - Contracts cstablished between the research institutes involved and industries for the establishment and improvement of their testing laboratories.

8 - Know-how and research support for ABNT. 
7 - Contracts established between the research institutes involved and industries for the establishment and improvement of their internal standardization and quality control systems.

10- Certification markings given to specific production lines of different industrial sectors.

11- Personnel trained in standardization, testins and quality control to industry.

12- Topics for research and development projects suggested.

Magnitude of outputs

FY 73 - Research institutes involved acting as reference laboratories in priority areas of manufactured products for export and for the State Government purchase agencles

- Long-range plan approved for the establishment of reference laboratories

FY 74 - Peference laboratories acting in the areas of chemical products, fron and steel products, industrialized agricultural products, machines and building materlals

FY 75 - Reference laboratories acting in the areas of home appliances, textiles, rubber products, and vehicles

FY 76 - Reference laboratories advising on uniformity in measurements and acting in the areas of furniture, clothes, and shoes, electrical products and electronic products

FY 77 - Reference laboratories established for the majority of industrial sectors.

Assumptions for achieving outputs

1 - GOB will continue providing incentives for export of manufactured products

2 - State Government will give the necessary financlal support for this project

3 - Positive results vill have multiplier effect on the industrial complex. 
GENERAL REMARKS ON THE PRESENT STANDARDS SITUATION IN BRAZIL

1. There is a natural dynamism for the establishment of standards between industries. Government action will be much more necessary towards the final consumer; note, however, remarks 4 and 6 .

2. There is a certain degree of diversification in relation to standardized materials, methods of tests and components due to the presence in the Brazilian industry of industrial traditions of different origins: American, French, Italian, English, German, and lately, Japanese. Government action will probably be needed to reduce this diversification, probably helped by the international standardization movement.

3. In the traditional industrial sectors, mostly developed by local entrepreneurship, production standards are largely nonexistent. Government action should have a strong educational component in this area. The subsidiaries of foreign companies have production lines rationalized, but they introduce the difficulties mentioned in 2 above.

4. Industrial standard parts, such as bolts, electric wires, electric outlets, fixtures, springs, transmission belts, etc., are, in general, of deficient quality, impairing the quality of the final products. The beneficial effects of Government action would probably be felt in this area.

5. Agricultural products, in natural state and processed, constitute a special problem due to the total nonexistence of standardization.

6. The building industry, particularly the housing sector, is divided by a large number of small firms which have been incapable of organizing themselves to represent a purchasing power. Consequently, they represent an exception to remark 1 .

7. The certification system will probably require regional laboratories to aid local industries; consequently, it will be necessary to organize a plan to homogenize concepts and procedures. 
8. Difficulties have already been experienced in exporting durable consumer goods, such as refrigerators and television sets, due to the nonexistence of the certification programs capable of assuring the quality of these products with sufficient credibility to be recognized by foreign consumers. 


\author{
IIEH IORANDUH OF UNDERSTANDIHG \\ BETHLEI TIE \\ STATE OF SAO PAULO REPLESLNTED BY THE \\ SAO YAULO STATE COUHCIL OF TECHivOLUGY (CET) \\ Aill) THE \\ WATIOHAL BURLAU OF STAHUARUS (NBS)
}

The Governnent of the State of Sao Paulo (Brazil) has developed a plan for the acceleration of industrial grovtin in this region, called the Sao Paulo Project in Science and Technology.

'the broad purposes of the Sao Paulo Project in Science and Technology are:

1. To pronote the application of basic and applied scientific research and technology to the problems of Brazilian industry and agriculture.

2. To develop the capabilities - in industry, governinent, universities and research institutes for providing an increased proportion of this research and technology from Brazilian sources, and

3. To focus efforts for increasing, capabilities in science and technology most closely on those industrial and agricultural sectors that hold promise for rapidly improving Brazil's economic growth, largely through improving the capacities of firms to compete successfully in world markets.

The Government of tine State of Sao Paulo is providing firms with financial incentives to invest in research and development projects of their own and to contract for research in Sao Paulo institutions, principall: research institutes and universities. By these contracts, the research institutes and universities may be expected to increase their capabilities to serve the firms and thereby contribute more effectively to the economic growth of the State and the siation.

This strategy is being implemented through a policy and decision-making structure, the Conselho Estadual de Tecnoloria (CET), which is applying the financial incentives and mobilizing supportinf resources of tecinical assistance and inaterial procurement. U.S. technical assistance and training services are being provideu in support of the program by the AID Loan :To. 512-I-U88. 
This lienorandum of Uncierstanding provides the basis under which the ivational Bureau of Standards (INBS) agrees to furnish scientific and technical advice and assistance on a reirbursable basis to CEI in support of a collaborative program to enhance the scientific and technological capabilities of Brazil.

The objectives of the prograri will be to create and inprove capabilities at the Instituto de Pesquisas 'fecnologicas (Il'T), which rrovicies consultation services to the manufacturing industry and which will make a direct contribution to measurement systems and product quality with possible benefit througinout Brazil.

The program will include:

1. Iraining at iJbs or at other governmental and private institutions

2. Supply to IPT of research materials, physical standards, or instruments for precise measurement or quality control

3. Participation of IPT in ivBS prograns

4. Technical assistance, including consultation assigments of ITS staff to IPT

5. UBS services normally given on a reimbursable basis.

The program vill be developed in project areas (see $A-G$ below) through the identification of a series of specific tasks in these areas and allow for addition or deletion of specific tasks. Each task will give as an end product a new or enhanced capability of IPI to perform a certain service to the Brazilian industrial community and/or government.

Each tasic plan will include: purpose of the task, names of tine monitors at iBS and at IPT, assumptions for achieving purpose, inputs by IJBS and by IP' $\Gamma$ and dates thereof, expected milestones towards completion, reports and dates thereof, output indicators, budget, anci expenditures schedule. Each task must be approved in advance by the Coordinators for botn iBS and CLT. At the conclusion of a task, the monitors will prepare a final report which must be approved by the Coordinators for both NBS and CET.

Payment is to be made only for completed work on INBS requests for reimbursement by voucher against $A I D$ Loan 512-L-088 after approval by CET that the work covered by the voucher has been 
performed. The Council shall pay actual costs in cruzeiros of transportation of travelers in Brazil in connection with duties directly referable to the contract including travel allowances at rates prescribed by the U.S. Federal Governnent 'Iravel liegulations as from time to time amended. The Council will provide a per diem allowance (in lieu of quarters allowance) to short-term staff nembers at rates prescribed by the U.S. Federal Governient Iravel kesulations as from time to time anended, during the time such short-term staff menbers spend at posts of duty in brazil uncier tiris arrecinent. In autihorizing such per dier rates, the Council shall consider the particular circumstances invoived with respect to each such sinort-tern staff merber includin: the extent to winch meals and/or lodring may be made available without charge or at nominal cost by a brazilian agency and similar factors. Where travel or subsistence expenses in countries other than Erazil are involved for iDS or IPI staff or consultants, U.S. Federal Travel iegulations shall be applied.

Reimbursement shall be for all program costs, including such travel or subsistence expenses, salary, costs of plannins, other adrinistrative costs and overhead expenses as routinely recorded in the IIBS accounting: system $u_{p}$ to the linit of the attached budget. In case this limit has to be excecded an amended budget nay be submitted by IIBS for approval by CET. The Council will establish an irrevocable letter of credit in U.S. dollars at the liew York Office of the Banco do Brasil, acceptable to and in the name of the IIBS, riich will be in the same amount as the face value of this contract, and wilich vill be amended if the face value of the contract is chanced. I.BS may, upon approval by CET, transfer anounts between the several columns and rows of the budget, provided that the total budget figure is not exceeded.

'The agreed task shall fit into one of the iBS/IP'l project areas (as further defined in the following paragraphs $A-G$ ) within which the needs of industry will be especially considered:

(A) Chemical inalysis

1. Identification and evaluation of possible areas of application of $\mathrm{x}$-ray fluorescence, electron problem microanalysis, and related instrumental analysis techniques to industry, environriental problens, and applied scientific research.

2. Training and technical assistance to foster the correct use of Standard Reference laterials in Brazil and to develop the capability at IPT for producing, certifying and distributing reliable working standards. 
3. Transmittal of selected published documents and literature references of potential interest to IPI in above mentioned areas.

4. Discussion and evaluation of plans for applied research, traininr, and services in the above mentioned areas.

(I) Collaborative Reference Programs (CNP) (other than those covered uncer c. below)

1. Participation of IPT in IBS'S CRP's: such as rubber, paper, and color and appearance.

2. Iraining of IPT staff menivers in tive data analysis performed in CRPs (also to be used on the CCKL reference program, par. C below).

3. Training of IPT staff members in the planning and implementation aspects of these CRPs.

4. Training of IPI staff members (possibly the same individuals mentioned in 3) in specific testing techniques, possibly at selected laboratories participating in the CRP and at laboratories specialized in other products such as lumber, textiles, metals, plastics and ceranics.

5. Technical assistance for the initiation of CRPs in Brazil in product areas such as rubier, paper, and color and appearance.

(C) Cement and Concrete keference Laboratory (CCRL)

1. Participation of IPI on CiPs for cement, bituminous materials, soil, aggregates, and concrete.

2. Training of IPT staff members in the planning and implementation aspects of these progranis.

3. iraining of II'T staff memiders as laboratory inspectors.

4. Technical assistance for the initiation of CPSs and inspection prosrams in irazil for the procluct areas listed in paragraph 1 above. 
(D)

Measurements Services

1. Assisting IPT in acquiring and/or maintaining "stand alone" capability in dimensional, mechanical, optical, electrical, heat and allied areas of measurement.

2. Supporting the transfer of measurenent capability to practical measurement.

3. Training of IPT staff members in selected areas of measurement where the needs of industry are not being met.

(E) Building Research

1. Training of IPT staff members in performance testing and development of test methods, with emphasis on aspects of durability and safety, in the iNBS Center for Building. Technology and the Fire Technology Program.

2. Assisting in the transfer of the present state of the art in the U.S. and specifically at MBS in buildin: technology, specifically related to structural engineering and building standards and codes, and housing technology.

(F) Information Activities

1. Provision of selected U.S. literature on standardization and measurement science and technology.

2. Training in utilizing available services at iNBS in information systens for science and technology and the NBS reference collection of standards.

3. The use and dissemination of critically evaluated technical data.

4. Training of IPT staff members in planning and development of techniques, procedures and mechanisms for resolution of obstacles and for the establishment of incentives for computer applications for information systems. 
1. Technical training assistance needed to implement prograns of laboratory examination and evaluation.

2. Consultative assistance concernin? a system of examination, evaluation and monitorine of testins; laboratories, to be applied in furtierance of other elements of this argreenent.

Then trainin: necessary for the accomplishment of any arreed task is not available at iBS, this training way be accoraplished by contractinc with other public or private institutions or organizations defined in the task plan approved by IBSS and CET. The prograri may involve additional trainine in areas mutually acreed by WBS and CLT. All contracts witi non-jovernmental institutions or or "sanizations shall contain provisions required by law or U.S. Governnient policy and siall be approved by CET.

ioth the CET and IDS will appoint prograr coordinators with responsibility for effectively carryin out all phases of this progran. The greatest possible flexibility in the adrinistration snall be accorded to the coordinators coupled with full responsibility and accountability. Administrative status reports will be prepared by the coordinators on a quarterly basis. These reports and the incorporation of new tasks must be approved by IIBS and CET. Twice a year, a substantive evaluation report with full fiscal data will be presented by the coordinators for the review and evaluation of the collaborative program by iSBS and CLT. lieview and evaluation procedures vill include a joint meeting among officials of both CET and IiBS to consider reports presented by the coordinators. preliminary internal review procedures will be established by each organization in accordance with its orm needs.

This Understanding shall be in effect for two years from that date of signing. It may be terminated by either side, inmediately after written notification, but without affecting previously agreed and current tasks. Tasks in specific project areas nay be added or withdrawn by mutual consent. The Understanding may be amended or extended for periods of two years by a simple exchange of letters and establishing mutual consent. Ilutual consent for 
additional tasks or an extension of the period of the Understanding will require agreement for any additional funding that nay be necessary.

$\Lambda$ pproved and iccepted for

Sao l'aulo State Council of Technolosy Lye -

Secretary of Economy and Title: Planning

Date:

September 6, 1974
Approved and Accepted for the ivational fuztau of syndaxds

Ly:

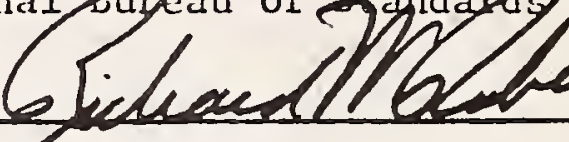

Director

ritle:

September 6, 1974 Iate:

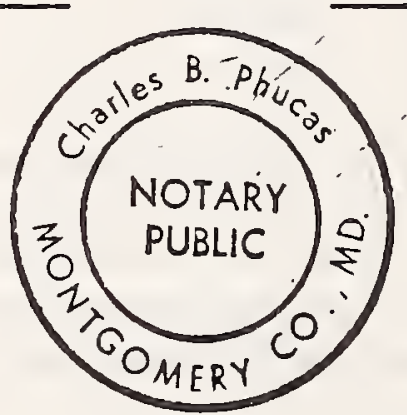




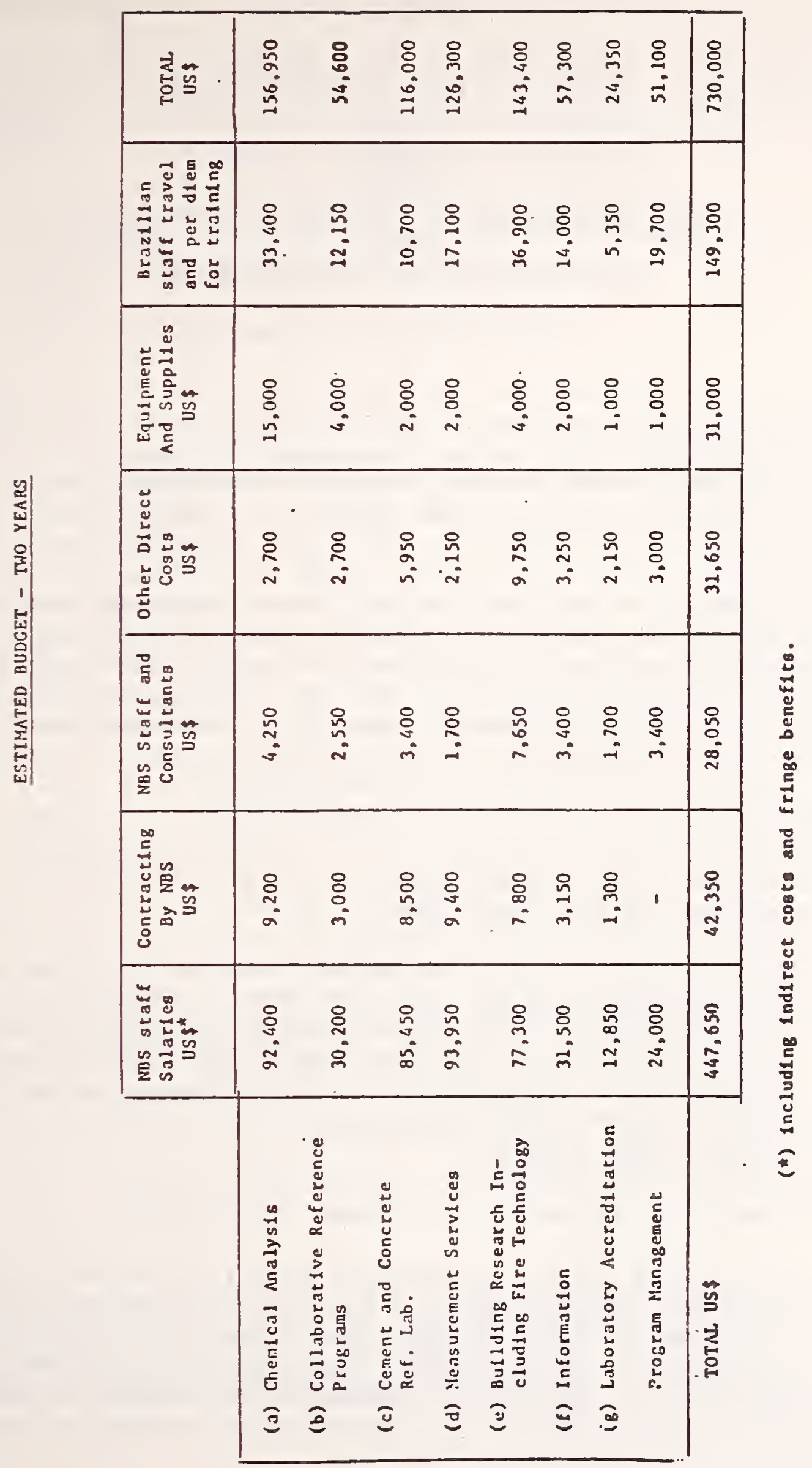


REPORT OF THE EVALUATION PANEL

$$
\text { OF THE }
$$

NBS/IPT COLLABORATIVE PROGRAM

BETWEEN

THE INSTITUTO DE PESQUISAS TECNOLOGICAS

$$
\text { AND }
$$

THE NATIONAL BUREAU OF STANDARDS

First Annual Review, June 1975

In accord with the Memorandum of Understanding (MoU) (see Appendix I) between the Conselho Estadual de Tecnologia (CET) and the National Bureau of Standards (NBS), the first annual review of the collaborative program between NBS and the Instituto de Pesquisas Tecnologicas (IPT) was held at the NBS site at Gaithersburg, Maryland, on June 25 - 26, 1975. The purpose of the Review was to evaluate the NBS/IPT Collaborative Program, which has been underway nine months. It was decided that this was an opportune time both to take stock and to identify opportunities to improve the Program. The list of Review participants is given in Appendix II. The IPT team at the end of the Review submitted their summarized views in a special document (Appendix III) on which this report has drawn freely.

The Program Review was conducted in three parts:

A. Welcome, introductory remarks, and descriptions of organizations and their programs.

B. Presentations ordered by project areas as laid out in the MoU were given by NBS task monitors. In these presentations task objectives were articulated, means of attaining these objectives were stated, and outputs described. Each NBS task monitor concluded his individual presentation with a brief evaluation and suggested recommendations for future program improvements.

C. Suming up by serior staff from NBS and IPT.

The purpose of this report, prepared on behalf of the NBS/IPT Review Panel, rather than to duplicate the task descriptions which are available in reports, is to collate and summarize the major points arising during the two-day program. These items constitute a report on the management of the NBS/IPT Collaborative Program to date, and also Identify aspects which can be improved and made more effective and efficient in the future. 


\section{OVERALI EVALUATION OF PROGRAM - OUTPUT BENEFITS}

From both the IPT and the NBS point of view, the results of the Program are clearly positive. The Program has been successful in transferring to IPT staff some of the technological capabilities now in use at NBS. NBS should continue in its triple role of:

1. Serving as benchmark for the quality and the depth of IPT measurement and analysis services to industry, other governmental agencies, etc., in Brazil.

2. Helping IPT develop new capabilities.

3. Assisting IPT to maintain technical awareness.

The first item is particularly important in a rapidly developing country, since measurement standards and associated data are essential for the unified, consistent measuring system required by extensive industrial activity.

The selection to date of areas for collaboration shows a good mixture of immediately practical and of high technology. IPT clearly knows how to define its short-term needs and to take steps to meet those needs. However, probably the greatest potential benefit of this collaborative program is in its long-range contributions. Continuing careful planning is essential to insure success in the long run. IPT representatives requested increased participation by NBS staff members in the planning and implementation of programs to meet long-term needs, as identified by IPT. It was suggested that problems be identified whose solution would benefit both countries. Good joint planning is needed to maximize useful outputs to both countries. Technological areas of concern to both Brazil and the U.S. Include housing, machinery and heavy equipment, electronic instrumentation, energy, and railroad transportation; the roles in these fields of both NBS and IPT on their national scenes are constantly evolving and great care is needed to define joint projects.

The emerging role of the Conselho Nacional de Pesquisas (CNPq) as the national coordinator of research was described. CNPq is interested in broadening the collaborative program to include other Brazilian institutions, exercising due care not to interrupt ongoing NBS/IPT collaborative activities.

Long-range programs, by their nature, are investments whose returns accrue over many years. To assist participants in gaining an appreciation of the short-term benefits already being received from the NBS/IPT Collaborative Program, it is useful to identify the 
benefits cited during these review sessions. A summary of these benefits, as seen by the NBS and IPT participants, follows.

\section{A. Benefits of Program to IPT}

IPT as an institution:

1. Obtains rapid and timely training by its staff to increase capability of IPT to serve the needs of Brazilian industry. This increased competence should be quickly reflected in IPT outputs.

2. Gains experience in working with advanced technical institutions like NBS.

3. Acquires skills that can be used to transfer technologies to other states in Brazil, and to national government agencies.

4. Observes the importance and utility of long-range planning and becomes more skilled in the planning process.

5. Gains experience in the establishment of institutional priorities.

6. Learns to respond to needs in Brazil more rapidly and efficiently with the possibility of back-up support from NBS in joint projects.

\section{B. Benefits of Program to NBS}

NBS as an institution:

1. Supports U.S. foreign policy objectives by establishing strong personal and institutional bonds with a major Brazilian institution. The experience in Brazil will help NBS judge how good our methods of collaboration are for general application elsewhere. This experience will help us understand better the scientific and technological needs of a developing country, and thus better understand our own needs.

2. Helps to develop and strengthen a Western Hemisphere approach in international standardization activities.

3. Obtains additional opportunities to observe the effectiveness of methods of technology transfer in situations different from those in the U.S., but sufficiently related so that NBS learns from the experience. 
4. Recelves intellectual stimulation for NBS staff. Contact with new problems promotes creativity and makes one think about different approaches to solutions.

5. Promotes new markets for U.S. technology, Instruments, and machinery by introducing U.S. products to the staff of an important Brazilian technical community. As the Brazilian economy develops, Brazil and the U.S. should become better trading partners.

6. Gives opportunities to 1ts staff to broaden their intellectual and social horizons through personal associations with the professional staff of IPT and other Brazilian organizations.

7. Obtains opportunities to use IPT facilities not available at NBS, and IPT staff support for NBS projects.

\section{Benefits of Program to IPT Trainees}

1. Provides opportunity for young Brazilian scientists and technologists to obtaln rapid professlonal growth.

2. Provides professional study and training where such courses are not avallable in regular training institutions in Brazil.

3. Affords trainees an opportunity to become familiar with the procedures, techniques, and problems faced by their peers working in a similar organization in another country.

4. Provides experience that will be useful in planning their work activities when they return to IPT.

5. Affords trainees with opportunities to explore other means of performing work in their activity areas, thus broadening and strengthening their judgment.

6. Provides trainees with a broad view of scientific endeavor as cooperatively practiced in the international community.

\section{RECOMENDATIONS}

Recomendations are presented in two categorles: A - Planning; and B - Implementation. Administrative and operational recommendations 
have been noted elsewhere by the program management, and a number of them are already being implemented. IPT representatives feel that many of the recommendations have the common purpose of advocating the clear definition of joint projects implemented by mixed IPT/NBS groups to benefit both institutions.

\section{A. Planning}

1. Task definition. Much thought is required from both IPT and NBS personnel. NBS needs to know better what activities the IPT laboratories are intended to support, e.g., at what level to approach industrial needs. NBS scientists and engineers with a broad knowledge of industry and the interrelationships of national business activities should visit Brazil to become better acquainted with the needs of local industry. This is a prerequisite to the provision of sound program planning counsel by NBS.

2. Matching new capabilities with new IPT tasks. A knowledge of NBS's capability to provide consultation and training and of IPT's capability to initiate new services is extremely important to effective planning. IPT has already found that the initiation of new services to employ new capabilities developed during assignments at NBS is sometimes slower than originally planned. (The problem is exacerbated by difficulties of importing necessary equipment.) Some tasks might slow down and priorities be rearranged. (Interestingly, the training of $\mathrm{Mr}$. Ikeda resulted in a realization that LESS not MORE equipment was needed by his IPT Division than was originally requested by that division.)

3. Briefing of trainees. After being selected for training, and before arrival at $\mathrm{NBS}$, trainees should have a clear vision of their individual objectives and their future institutional responsibilities. Each trainee should also be briefed by appropriate IPT officials on institutional objectives for his training. Appropriate questions to be addressed in the briefing include: What techniques are to be acquired? What basic fundamentals should be understood because they underlie these techniques? Is research needed on methods, including their range of applicability to particular types of IPT samples or problems?

4. NBS/IPT Program. IPT suggest that NBS play a more active role in planning the future tasks in the NBS/IPT Program. NBS agrees to explore the extent to which it is practical for NBS to undertake this role. 
5. Priorities. Management specialists at NBS might assist in selecting priorities and in overall planning to help achieve a balance between long-range needs and the more immediate pressures on the training program.

6. Timing. Good planning requires adequate lead time. Yet flexibility is also needed. For instance, trainees should have as much flexibility as is needed to adjust their programs after arrival at NBS.

7. Communication of results. Planning should take into consideration the need of IPT to obtain progress reports, written or by personal appearance, even before the conclusion of longterm training assignments. IPT must attempt to put into practice new capabilities as soon as possible.

8. Tasks of specific programmatic interest to NBS. Flexibility should be provided for occasional introduction of tasks in which NBS obtains direct benefits to its major programs from services rendered by IPT.

\section{B. Implementation}

1. Duration of training. Some task monitors felt that the duration of training tended to be too short and should be extended.

2. Consultation on IPT mission. As NBS scientists and engineers become more familiar with the needs of Brazilian industry and with the nature and extent of avallable facilities at IPT laboratories, they will be in a better position to train IPT personnel and also to offer advice on what IPT should do.

3. Information centers. IPT trainees, whenever feasible, should familiarize themselves with information centers such as those supported by the Office of Standard Reference Data while at NBS, and with other information resources of the United States.

4. NBS staff travel to IPT. Consideration should be given to sending some NBS scientists or engineers to give lectures, engage in discussions, or to provide other kinds of consultation in Brazil.

5. Industrial surveys in Brazil. IPT should survey sectors of Brazilian industry to identify and quantify measurement problems. 
6. Professional interactions. As new measurement capabilities are brought on line by IPT, it will be useful for IPT to continue (as has been its normal practice), to interact with local user groups in Sao Paulo to solve problems and to exchange skills and technologies.

7. Follow-up to training tasks. Evaluation of the program should include a follow-up of individual trainees by subsequent interviews in Brazil, to ascertain the extent to which the benefits to Individual trainees extend to IPT outputs and to Brazilian industry. (See Benefits to IPT, Item 1.) 
A NATIONAL CERTIFICATIOIV SYSTEI FOP CHILE

\author{
Dr. Hugo Brangier M. \\ Executive Director \\ National Institute of Standardization \\ Santiago, Chile
}

\title{
I. A Short History
}

Chile is a developing country whose economy has been characterized since 1940, when the Production Development Corporation was created, by a systern of import substitution and protection for domestic industries. This was achieved by imposing high customs duties which have prevented free competition from abroad and by using systems of exchange for foreign currency which have discouraged the importation of goods. This has given rise to a Chilean industry which is basically desioned to produce goods for the domestic market, which, due to the lack of foreign competition, had to be satisfied with merchandise that was of dubious quality as well as generally more expensive than comparable goods in other countries.

It is also appropriate to point out that during certain periods programs to increase nontraditional exports were formulated. One recent period that comes to mind is the 1961 to 1970 period, during which specific actions were taken to improve Chile's balance of payments through greater exports, mainly from the agroindustry and the metallurgical industry.

All of these activities undertaken from 1940 to 1973 drew their inspiration from a soclalist oriented view of the marketplace, as the state's participation in and direction of the economy became increasingly more important.

\section{The Current System}

The government that has controlled the destiny of our country since 1973 has stated as its basic premise that the nation's economic development will be achieved by implementing a free marketplace policy and a sound and aggressive foreign trade policy. A precondition for the free market economy is the institution of a system of real competition among the nation's industrialists and vis-a-vis goods from abroad, a competition deriving from a plan for genuine efficiency among businesses. This gives rise to a higher production of better quality goods which must enter the market at a cost that is comparable with similar goods from abroad. Thus, the consumer is fully satisfied because he is guaranteed a fair price for what he is buying. 
The proposed foreign trade policy involves:

a) a gradual reduction of import duties;

b) export incentives, through the establishment of realistic exchange rates for foreign currency;

c) fulfillment of the comitments that have or will be approved within the Cartagena Pact (Andean Common Narket);

d) an agressive attitude on the part of Chilean manufacturers in terms of acquiring, and holding forelgn markets.

Therefore, the nation's industries face the challenge of:

- winning over the Chilean consumer by offering high quality, reasonably priced products;

- defending their products vis-a-vis imported goods; and

- entering foreign markets and competing with local goods and imports from other countries.

III. Conditions for Implementing the Proposed Policy

In order for the proposed policy to be successful, the following steps are necessary:

a) improve industry efficiency, through the replacement of old equipment and the use of technologies that are consistent with mass production;

b) Improve the presentation and quality of products for the domestic market and especially of products for export;

c) institute quality control systems for production, in order to guarantee the consumer acceptable and steady quality; and

d) develop a system of quality certification, either by lots or on a permanent basis, which will substantiate the guarantee to the consumer. 
IV. Qaulity Certification

A. Organizations in operation until the present time.

Together with the domestic industry for import substitution, various organizations and systems arose which tried to provide technical assistance and, to some extent, laboratory services for Chilean manufacturers. Moreover, the state became involved, to some extent and for certain items, with exercising various controls on incoming materials and parts. Together with this, organizations were created as branches of the state and mainly of the universities, which established standards and/or carried out control testing, most often on incoming lots of specific products. Although it is not an exhaustive 11st, we can cite the following groups:

1. Direct branches of the State:

- Superintendency of Customs;

- SEGTEL (Superintendency of Electrical Services, Gas and Telecommunications);

- SNS (National Health Service);

- SAG (Agriculture-Livestock Service);

- SOQUI:IICH (Chilean Chemical and Mining Association);

- Air Force laintenance Wing;

- IDIC (Army Institute of Research and Contro1);

- ECA (Agricultural Commerce Enterprise);

- Central Bank of Chile;

- CODELCO (Copper Corporation); and

- Road System Laboratory, Ministry of Public Works.

2. Branches of the Production Development Corporation:

- INFOR (Forestry Institute);

- IFOP (Fishing Promotion Institute);

- SERCOTEC (Technical Cooperation Service);

- INDITECNOR (National Institute of Technical Research and Standards):

and later,

- INN (National Standards Institute);

- Technological Research Cormittee (Chilean Technological Institute-Production Development Corporation);

- INACAP (National Professional Training Institute); and

- CESME (Ketallurgical Services Center).

3. Direct branches of the universities (In this case, only laboratory and, in some instances, certification services are provided): 
a) The University of Chile:

- IDIEM (Institute for Materials Research and Testing);

- Food Technology Institute;

- IDIEF (Institute for Pharmacological Research and Testing);

- Electronics Department, School of Engineering;

- Mechanlics Department, School of Engineering;

b) The Catholic University of Santiago:

- DICTUC (Department of Scientific and Technological Research);

c) the Catholic University of Valparaiso:

- Lighting Engineering Laboratory;

- Marine Products Laboratory;

- Chemistry Laboratory;

d) State Technical University:

- School of Arts and Crafts, in Santiago;

- School of Industrial Engineering, in Santiago;

- Concrete Laboratories, provinclal headquarters;

e) Federico Santa Maria Technical University of Valparaiso:

- Mechanics Deparment;

- Chemistry Department;

- Metrology Department;

f) University of the North:

- Electrical Engineering and Electronics Laboratory;

g) University of the South:

- Milk Institute.

4. Finally, other private laboratories appeared, such as COPREMA (Materials Suppply Company) among others.

Each of these entities operated and operates in an independent fashion, with its own testing procedures. Only in some cases were procedures approved in INDITECNOR (later INN), national standards utilized, and most often these groups developed their own varlations of these procedures, without coordinating them through a nationwide system. 
All this has led to a chaotic situation with an uncoordinated system of standards, quality control, and certification, to the extent that certificates 1ssued by one laboratory are not recognized by other labs or by users.

Te must go on record and state that many of these groups have long years of experience in carrying out control tests, since they were designated as "official laboratorles" for incoming product lots; this is the case with IDIEM, which since 1940 has exercised control over bars for reinforced concrete. In addition, these recently created groups are operated efficiently and lend prestige to the organizational machinery in Chile today.

B. lieed to reform the current system

CONICYT (National Commisston for Sclentific and Technological Research) is envisioning general and specific policy measures related to this fleld, within the framework of the proposed ilational Plan for Scientific and Technological Development which was presented to the sovernment in 1974:

a) General policy

- Techniques and services in the area of quality control, standards, and metrology will be expanded and improved.

- A new set of provisions w111 be established to regulate the obligatory use of quality standards and measures.

b) Specific policies

- The use of a seal of standardized quality will be required for goods produced by domestic industry.

- Rigorous supervision will be required to insure compliance with this measure in regard to goods for export.

- Careful supervision will be carried out to see that the advertising of domestic goods is consistent with their actual qualıty.

- Support will be given to the National Standards Institute in the area of technical and infrastructure improvement, so that it can fully carry out its functions.

- The National Standards Institute will be able to authorize certain organizations to issue the certificate of the seal of standardized quality. 
- Credit and informational facilities will be provided to the production sector so that it can comply with the measures that affect it.

- A pilot project will be developed through the State Supply Directorate to perform rigorous inspection concerning the quality of goods purchased by the state.

In consideration of the above and in light of the challenges facing domestic industries and the country itself, as well as the overriding need to take better advantage of the nation's resources, we come to the conclusion that a national quality certification system must be established for the domestic production sector, both in terms of the domestic market and goods for export.

Considerations similar to those mentioned here should have been taken into account when Decree No. 858 of the Ministry of Economy, Promotion, and Reconstruction, as published in the officlal diary of 29 August, 1964, established the National Coordinating Council for the Application of Production Standards and Quality Control as a branch of the Industry and Trade Directorate. For reasons which are not appropriate to analyze here, this council was never organized and therefore never began operations.

We feel that the time has come to make quality control more of a reality in our country. This idea is being volced in many different areas but has not yet taken shape, although by now no one can fall to recognize that quality control, as a tool, is an indispensable part of the modern firm. It is the element that wlll allow the foundations to be laid for industries of future importance and will enable the market to expand, both domestically and internationally, through the sale of quality products at competitive prices.

C. Basic ideas for implementing a national quality certification system

The full Implementation of a quality certification system is important in terms of goods for domestic sale, and it is vital for export goods. Nevertheless, in light of the present economic situation, efforts should be focused on quality certiflcation for exports and imports and only for certain categorles of goods for the domestic market, since it would not be appropriate to raise the cost of other items to be sold internally. In any case, these measures should be continually implemented with a view towards the time when the country will enter a period of economic upswing, after demand problems have been overcome and under the stimulus provided by exports and the Supreme Government's policy of economic recovery. It must be kept in mind 
that it is not easy for a country to acquire foreign markets without the backing of the domestic consumption of the products involved, and therefore the aforementioned strategy must be examined in depth.

Over and above the structure of the system to be used, what is important is that it be consistent with the reality of our economic process, with an improved coordination of existing resources in compliance with certain basic guiding principles, and with the demands that are involved in commercial transactons with these products. This means understanding and studying the real or projected demands of the market in which the standards set up by the system would be applied, as well as the reality of our industrial sector, so that the quality of domestic products can be gradually improved in accordance with the technological development of this sector.

Inportance should be attached to the need to comply with the quality control required for certain products which are considered of strateglc importance for the nation's populace and economy, such as, foodstuffs, industrial security items, export goods, raw materials or inport goods, etc.

A seal of quality should be established for Chllean products that meet standard specifications to show that the responsible bodies have certifled their quality, whether they are produced by large, medlum size or small firms. In this regard, a single distinguishing seal should be designed for the use of the varlous certiflers.

Training in the area of standards and quality control is needed for both public and private officials as well as for manufacturers and consumers, so that they can act in support of a system that will be to their own benefit.

The need to produce quality goods must be understood by all the elements in a firm: workers, supervisors, technicians, etc. ("Companywide Quality Control" in Japan). This issue must be brought to the attention of all national sectors, both public and private. Awards should be established for the companies which do the most for the quality of their products, practice quality control or obtain favorable results when subnitting their products for review by the responsible organizations. Special "weeks" should be held, in which state entities, private firms, consumers, students, etc., would take part, to emphasize the importance of quality control.

It is important to link the implementation of the system with the agreements that are in force in the area of foreign trade: the Andean Group, LAFTA, etc. 
The system must not be based only on the government enforcing a given degree of quality control. Each firm must implement measures in support of quality control.

D. Proposal on a structure for the system

In light of the existing infrastructure and the need to make better use of it under a specially designed system, we propose that a National Standards and Quality Control Commission be officially established. It would be equivalent to the National Coordinating Council for the Application of Production Standards and Quality Contro1, which was created by Decree No. 858 of the Ministry of Economy, Promotion and Reconstruction. This decree should be amended in terms of the makeup and functions of the commission, in accordance wth a review to be made by the Economy Ministry and the proposals of the present study. Its prime objective would be to coordinate the work of the National Standards Institute with the various existing laboratories in organizations such as CESME, IDIEM, SERCOTEC, and the universities in general, etc.

In diagram form, the potentlal certification system could have the following structure:

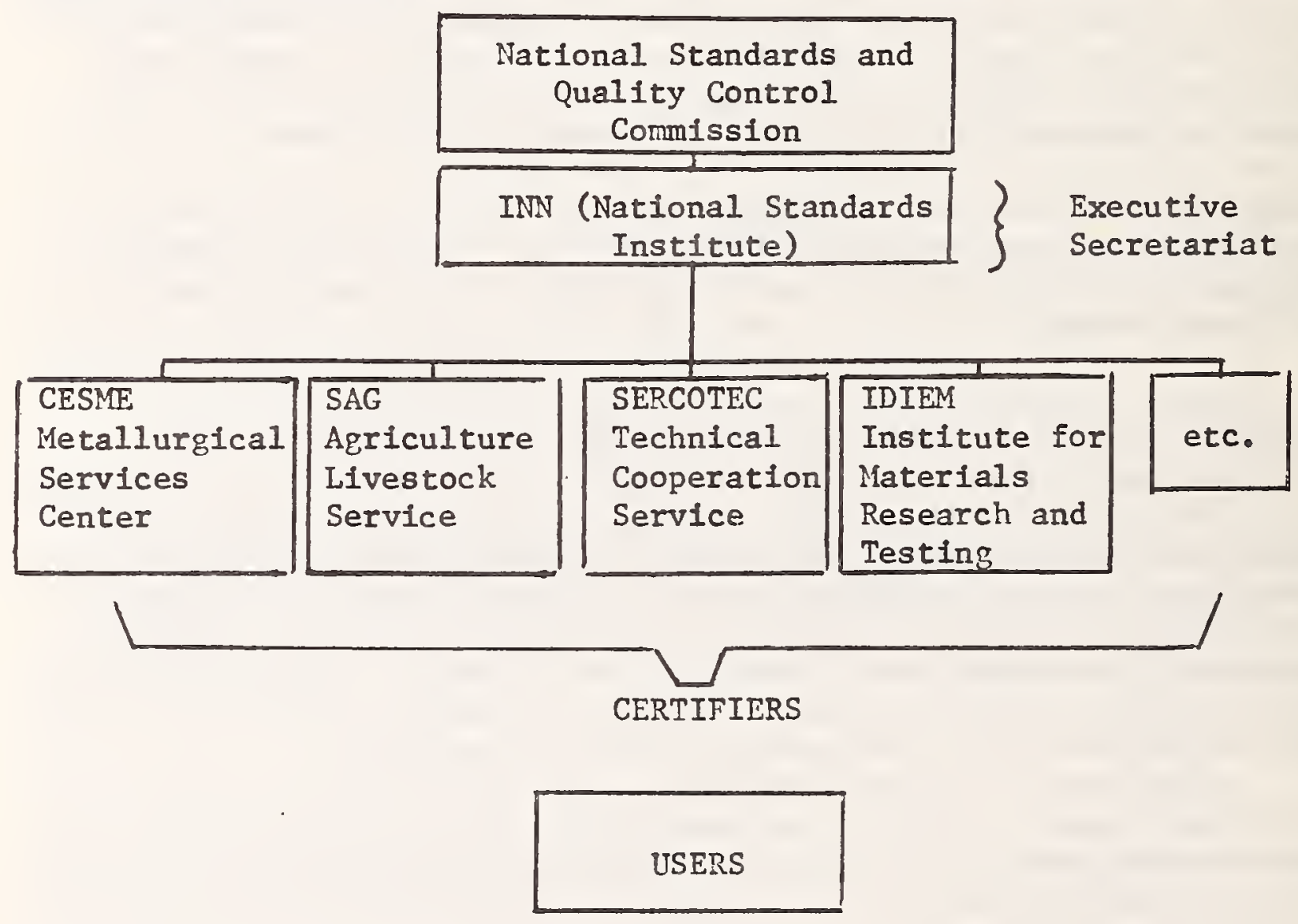




\title{
STANDARDIZATION IN COLOMBIA
}

\author{
Ir. Jorge Enrique Barrios \\ Chief, Chemistry Division \\ Colombian Institute of Technical Standards \\ Bogota, Colombia
}

Standardization in Colombla was born through the initiative of private industry in answer to the need to improve the quality of products on the domestic market and especially those for exportation. As a result of this need, in 1963, the Colombian Institute of Technical Standards [ICONTFC] was created with the specific function of setting quality standards for products.

This body is a nonprofit organization and is the only advisor to the national government in standardization by decree-law. In Colombia as in many other countries, technical standardization is carried out on the basis of participation by the three maln sectors: the common interest, the producers and the consumers. There are present1y 30 divisions operating in the Institute and they cover all fielis of industrial technology and production.

During the past 12 years of hard work, ICONTEC has managed to establish around 1,100 standards in addition to the Colombian Electrical Installations Code for Housing, the Public Lighting Code and the National Sanitation Code, this last one in collaboration with the Colombian Ministry of Public Health.

Being a private institute, ICONTEC receives no economic support from the government. It is maintained by the annual dues paid by its subscribers. The amount of the dues is determined in accordance with the company's gross capital.

It should be noted that ICONTEC is not responsible for the enforcement of the standards; that function is the duty of the national government through the Superintendency of Industry and Commerce and the corresponding ministries.

Considering it necessary to establish a system of quality control, the government created the National Council for Standards and Quality to set up an organization which would be in charge of making standards officlal.

As a result, ICONTEC created the Quality Control Division, with the responsibility of providing consultation on quality control to its subscribers, giving certificates of quality for products exported or 
imported and verifying the fulfillment of the quality requirements established by the government for consumer products.

In reponse to the need for permanent training in standardization and quality control, ICONTEC, through the Quality Control Division, gives courses every year on total quality control, for the purpose of spreading these disclplines into all public and private sectors.

ICONTEC's operation has been especially beneficial for Colombia because of its participation in the Andean Group, as well as its capacity as a member of the Pan-American Technical Standards Commission and the International Organization for Standardization. Colombia has been able to achieve more effective work in the area of product standardization than those countries lacking a national standardization institute.

Considering the infrastructure now existing in Colombia as a developing nation and the challenge Colombian national industry is facing because of the policies laid down by the current government, it is now more important than ever to have effective quality control in Colombia in order to sell good products at competitive prices. Because of all this, ICONTEC is more committed than any other Colombian organization to making quality control a real national goal. 


\section{SECTION ON WEIGITS AND MEASUREMENTS}

Dr. Josefina Espaillat Duran

Under-Secretary of State for Industry and Commerce

Head, Standardization and Quality Control Department

Santo Domingo, Dominican Republic

\section{Background}

The Dominican Republic is a country that has undergone a series of socio-political changes with the result that it can be considered now a country that is definitely developing. This development is increasing rapidly in the areas of industry, tourism and mining, and the effect of this is reflected significantly in the national econony.

With respect to our industrial development our most pressing need is an adequate and rational system of norms and standards.

Even though there is in our country a law dating from 1954 which establishes a system of weights and measurements based on the metric system, the implementation of this law has been slow and it proved to be much more difficult than originally anticipated. The result has been a postponement in the application of the law. Not all has been lost however, since we propose to use the experience gained in the implementation of the metric system under the sponsorship of the Department of Standardization and Quality Control, which at the present is under study in the Secretariat (Ministry) of Industry and Commerce in my country.

\section{Projects of Standardization}

There is at present a project under study which would establish a Department of Standardization and Quality Control as an office of the Secretariat of Industry and Commerce which would, among other things, be responsible for the preparation of industrial standards necessary to enforce minimum standards of quality for national products including those that are produced for local consumption as well as those for export. Similarly, another department within the same organization would be charged with enforcing mandatory standards which are designed to protect health and safety.

It is necessary to establish priorities in the determination of standards of quality in accordance with internal needs and the import requirements, keeping in mind that the purpose of establishing standards and norms, is to fix the characteristics of each type of 
finished product which will ensure their adequacy for their intended use and in a way that the component elements may be used to the fullest extent possible.

The standards and norms make it possible for owners of industries to rationally regulate the resources for their plants and to demand from their suppliers optimum quality so that they can turn out an adequate finished product. It is logical and desirable that in the process of establishing a system of standards and norms for a country, a policy of maximum adherence to international standards in world commerce be followed since this will obviously make it easier to comply with agreements regulating world comerce and will render national products much more accessible to world commerce.

Hence, the Dominican Republic has felt the need of establishing an institute that wil1 establish standards which w111 help to define the patterns and norms for raw materials that go into manufactured goods.

\section{Standardization}

Our project for the establishment of a Department of Standards that could serve as a guide to the industrial manager as well as to the consumer, but that in any respect might be eminently pragmatic, is considering the establishment of a section of standards whose patterns we could expect as a result that the producer, the governmental office and the user would use common language.

Among the units of measurements that we wish to have in the future, and those which we consider of prime urgency are the ones that are related to mass (weight). Among those one should note, there will be a requirement for those presently in use and also the ones anticipated, all of which w111 constitute in the future the national sys tem.

It is because of the enormous amount of work we must develop rapidly that we are asking for the assistance of the vational Bureau of Standards and their experience, particularly in regard to patterns of certified weights which follow in tabular form.

Metric System

\begin{tabular}{|c|c|c|c|c|}
\hline 0.500 & g. & 50.000 & $g$ & 25.000 \\
\hline 1.000 & g. & 100.000 & g & 50.000 \\
\hline 2.000 & g. & 200.000 & $g$ & 70.000 \\
\hline 3.000 & g. & 500.000 & $g$ & 100.000 \\
\hline 4.000 & g. & 800.000 & $g$ & \\
\hline 5.000 & g. & 1000.000 & $g$ & \\
\hline 7.000 & $g \cdot$ & 2.000 & kg. & \\
\hline 0.000 & g. & 5.000 & $\mathrm{~kg}$. & \\
\hline 25.000 & g. & 10.000 & $\mathrm{~kg}$. & (Total 22 \\
\hline
\end{tabular}

English System

1 oz. avdp.

4 oz. avdp.

$1 / 2$ Ib. avdp.

1 1b. avdp.

2 1b. avdp.

$41 b$. avdp.

5 1b. avdp.

$101 \mathrm{~b}$. avdp.

25 1b. avdp. (Total 12 Welghts) 
Believing that the i.BS is aware of tire importance of our project, as far as the standardization of units of weight is concerned, we wish to state clearly in our request our purpose towards the establishment of a system of standards in our country which will bring about the elimination of possible sources of deceit in the commercial sector.

In regard to the units of mass indicated in the above list one should note that at the present time in our business transactions in our country there is a mixture of units, some from the English system, some from the metric system, and other units inherited from old Spanish units.

Our process of standardization must begin with the verification and adjustment of the units now in use and must proceed torvards the establishment in full agrcement wth the other countries wich ma'ce up the Comision Panamericana de Jormas Tecinicas (COPAIT), of tio metric systen in a time frame that would be reasnnable to meet the :equirement of the industries thet will have to adjust and nofify tireir equipment.

We are convincel that with a systen of standards of quality which will encompass production for interna? consumption and crport, a tear of inspectors and technical advisors that will devote their time to demonstrations and confrontation of the product with the requirement of tire standard as well as the establishnent of a center of information that will broadcast the advantages of standardization for tine consumer and for industry, our country w11 be able to, in short order, catch up with those countries that are more advanced than we are in the area of standardization. 


\author{
Dr. Anwar E1-Tawil \\ Chief, Industrial Metrology Division \\ Egyptian Organization for Standardization \\ Cairo, Egypt
}

\title{
I. Historical Background
}

Egypt was one of the cradles of human civilization. The ancient Egyptian civilization, which was characterized by remarl:able achievements in building and irrigation, science and art, relied on a solid basis of well developed measurement and standardization. For example, length measurements were developed at a very early date to serve for the determination of the area of land flooded yearly by the iJile river. They were also used to carry out the great constructions undertaken by ancient Egyptians. To give an idea of the high level of accuracy attained by ancient Egyptians, suffice it to say that the squareness and level of the base of the Pyramid of Cheops (about 2700 B.C.) are true to less than one ten thousandth of the side. The standardization of the stones used for building the pyramids was a feat in itself.

Ancient Egyptians had a system of measurement with primary standards and substandards. They practiced periodic verification. Among the items exhibited in the Egyptian museum in Cairo are a lensth standard in the form of a granite bar of square cross-section with engraved lines, and marble standard weights.

The history of standardization and measurement in modern Egypt is closely related to that of the industrial development in the country. In the late fifties of this century, Egyot started on the way of intensive industrialization to raise the standard of living of its population, and to switch over from a backward agricultural economy to a modern industrial and agricultural one. In 1956 the Ministry of Industry was established, and a few months later a law on standardization was passed. The Egyptian Organization for Standardization (EOS) was established by a Presidential Decree early in the year 1957.

II. Activities of the Eryptian Organization for Standardization (NOS)

The EOS is a gavernmental organization charged with standardization, quality control and measurement. Since its establishment the EOS has exerted considerable efforts in these fields. Examples of its achievments are: 
1) Elaboration of Standards: About 1300 Egyptian Standards have been promulgated. They cover raw and semi-finished materials, finished products, testing methods, measuring instruments and methods of their calibration, etc.

2) Superviston of Quality: Very early after its establishment, the EOS started to supervise the quality of certain local products. Standards on products related to safety and public health and sone comodities important for the national econony wore made mandatory by ministerial decree. The EOS operates a system of quality supervision to assure that these products conform to mandatory standards. The number of such products is about 120 at present and it is steadily increasing. They include many export products.

To promote the quality of local products other than those covered by mandatory standards, the EOS started in 1969 a Quality Marking System whereby manufacturers can voluntarily apply for the EOS Quality "lark. This System involves inspection by EOS of the quality control activity in the firm (its functions, facilities and organization). It also involves tests on raw materials, semi-finished components and finished products, as well as perfodic and surprise survelllance of the quality level. The nuality Mark is a guarantee to the consumer that the product conforms to the relevant Egypt1an standard.

3) Ueasurement: EOS particlpated actively in the application of the metric system in Egypt which was achieved in 1961. In addition to the elaboration of measurement standards, EOS has planned for the establishment of a national system of legal, industrial and scientific metrology. A number of laboratories were established in the framework of this systen. Others are currently under establishnent.

The EOS took the inttiative towards updating the weirhts and measures laws and regulation in Egypt. A new act on welghts and measures has been subnitted to the legislative body for promulration. It includes a number of new features such as:

- a description of a system of standards and sub-standards for wide dissemination of the accuracy inherent in the units of measurement.

- The legal units are those of the SI.

- Regulations for personnel engared in legal measurements are set up.

- Tolerances on the measures and measuring instruments are specified according, to Egyptian standards. 
- Control by EOS of the instrument producing industry.

4) Training Activities in the Fields of

Standardization, $\mathrm{OC}$ and Measurement:

The EOS has initiated a number of training proprams in the fields of its activity. It has also participated in the planning and organization by other bodies (including educational institutions) of training activities. The training programs organized by Ens cover

a) Standardization - a 4-week, full-time training program including lectures and case studies;

b) Quality Control - a 5-weel, full-time training program for $\mathrm{OC}$ specialists including a theoretical part and practical application;

c) Engineering Measurements: a 3-week, full-time program;

d) Inspection of Weights and Measures - a 47week, full-time program.

III. Some Problems of Standardization and Measurement in Egypt

The conditions of industrial development in Egypt gave rise to a number of problems that might be encountered in other developing countries. In the following, we give a brief discussion of some of these problems with the aim of throwing light on them and exchanging experience regarding their solution.

\section{a) Choice of Basis for National Standards:}

Egypt makes use of cooperation with foreign industries to develop its national industry. Different industrial projects are established using technical assistance from different countries. As a result, standards issued for the products of such factories tend to resemble the national standards of the country that supplied the equipment and know-how. Such standards are sometimes not in complete harmony with other national standards. The EOS applies a number of rules to solve this problem:

1) In questions of a universal nature, such as the system of units, fits, tolerances, etc., international standards are taken as a basis for Egyptian Standards whenever they exist. When no international standards 
exist (as for example, in the scope of gear tolerances), the system applied in the majortty of local industrial enterprises is taken as a basis for a national standard.

i1) For products manufactured in one factory, the existing factory standard is taken as a basis for Egyptian standards, provided that it is suitable for the national need. At the same time it is compared with international standards if they exist in the relevant fielr. The possibility of producing according to the latter standards is investigated and, if they are found economical, the relevant international standards are adopted as a basis for national standards.

1i1) For products manufactured in several factories, a first attempt is made to adopt international standards if they exist in the relevant field. If not, the most up-to-date and developed factory standard is taken as a basis for national standardization. Usually, the discussions that take place between factory representatives in the technical comittees readily convince the parties involved of the advantages of applying the better standard.

llost of the problems mentioned above would not have occurred in the first place if international standards existed covering all fields of modern technology. Unfortunately, this is not the case at present. The lack of international standards can be clearly visualized if we compare the number of existing ISO and IEC standards and drafts with the number of standards issued by any developed country. The problen. is still aggravated by the fact that many international standards are not practically applied in countries that have accepted them in principle as a future trend. This makes it impossible to import material or equipment conforming to international standards from such countries. This, combined with economic difficulties and political considerations, puts serfous obstacles in the way of interchangeability and uniformity of production.

\section{b) Assurance of Interchangeability:}

Reduction of variety and assurance of interchangeability are considered as one of the main objectives of standardization. In Egypt considerable difficulties are met when this objective is translated into practice. The usual case is that equipment for different factories comes from different sources, which gives rise to an excessive variety of types and sizes, and to limited or no interchangeability. This situation represents a serious hindrance to the national exchange of products and parts, and consequently, to the integration of the national economy. Sometimes we find that local 
enterprises still depend on foreion companies to supply ther with tools and parts, while equivalent tools and parts are manufactured locally for fit with another system. lost of the bir enfineering companies are forced to keep a stock of tools and gages sufficient to cover several systems used inside the same factory. The econonical losses and the organizational difficulties that result from this situation are quite evident.

The solution of this problem is quite complicated. Economical considerations and the scarcity of foreign currency make the conversion of the equipment of all enterprises into a unified national system a difficult task. With these considerations our Organization did not make the application of national standards aiming at assuring interchangeability compulsory. At this stage we have only issued a number of such standards, based mainly on international standards. We are currently publicizing their advantages among local industries and higher engineering institutes. At a later stage we plan to start with compulsory enforcement of these standards according to carefully devised conversion plans that would comprise time schedules, guides and conversion tables. Another proposal now under consideration is to excercise some sort of control over the import of costly and longlived production equipment to promote interchangeability on the national level.

\section{c) Ouality Problems:}

Problems of quality are the most common type of problems, and the most widely recognized among the general public. In developing countries several conditions may cause non-conformity to quality standards. Examples of them are:

i) irregularity of the supplies of imported raw materials and variation of their specifications;

ii) difficulties in supplying necessary snare parts and replacement of imported production and testing equipment;

iii) lack of qualified personnel and of technical know-how;

iv) insufficient knowledge of existing national standards.

It is the duty of EOS to help local industries to overcome these difficulties. Through its plan for issuing standards, as well as through its quality marking system, the EOS carries out studies of the possibility of the replacement of traditional raw materials by local ones, and helps industrial enterprises formulate their needs of new equipment and spare parts and supports their demand with government authorities. The elaboration of national standards helps greatly to 
raise the quality, not only by making use of them as valuable tecinical documents, but also during the process of their elaboration and the useful technical discussions that they stimulate.

CoS offers consultation to local industries on questions of quality, trains their personnel and provides them with good contact with foreign experience by inviting foreirn experts to the country and by placing local specialists in training courses abroad.

\section{d) Measurement and Testing Faclitties:}

One of the important problems faced by EOS in its activities is the insufficlency of avallable testing and measuring facilities. This insufficlency greatly hampers the elaboration of standards on a sound basis, the quality control activity and the calibration of industrial measuring instruments. EOS makes use of factory laboratories and of some existing central laboratories, but the acute lack of a facility for industrial metrology and quality control has prompted fos to undertake the establishment of such a facility. The EOS Quality Control Centre at Anereya, near Calro (costing about $\$ 4,000,000$ ) is currently belng established. It comprises sections for quality control of nearly all products produced in Egypt, as well as sections for the calfbration of most industrial measuring instruments.

At the same time, the EOS has devised a System for the Approval of lleasuring, and Testing Laboratories. This System (resembling, in the field of measurement the ?uallty larkin? System in the fleld of quality) involves the inspection of personnel, equipment and organization of the applying laboratory and the control of its performance by the execution of control measurements and tests on standard specimens.

Conclusion

In this short survey I have tried to highlight some of the achievements, as well as the problems of standardization and measurement in Egypt. I hope that they will meet the attention of fellow participants and eminent experts present at this workshop, and that the ensulng discussions will indicate ways and means to promote standardization and measuring activities in my own country, as well as in other developing countries having similar problems. 
 \\ ir. Abder Rahman II-Keilani \\ Head, Weirints and 'leasurement Section \\ Directorate of Standards and Netrolory \\ ilinistry of Industry and mrade \\ Annan, Jordan
}

\title{
1. History
}

The Royal Jordanian Government has been well aware of the importance of standardization as an effective tool for implementing and promoting industrial develonment. Its interest in standardization dates back to the fifties when the country started industrial developnent. In 1960, the Government charged one of the foreign institutes to conduct a thorough study of standardization activities and to formulate the necessary legislation. This was further complemented by a study conducted by another foreinn expert. As a result of the above studies, the seven-year plan included sone recommendations for the industrial sector. The published recommendations read as follows:

"For the protection of consumers and the safeguarding of quality standards for exports, a standards bureau should be set up to report to the "inister of Industry and Trade." For implementation of this recommendation, a draft law for standardization was submitter to the Parliament and, when the Jordan Centre for Industrial Development was established in 1967, it included a separate section for standards. In January 1971, the Directorate of Standards was created within the Iinistry of Industry and Trade and, in the nest year, the Standardization Law No. 24/1972 was issued.

\section{Structure}

Tile Directorate of Standards is a governmental body completely financed by the Government. It is comprised of the following five divisions:

1) Division of Standard Specifications

2) Division of Quality

3) Division of Certification Marking

4) Diviston of Laboratories

5) Division of Weights and ileasures 
Since 1968 the Hashemite Kingdon of Jordan has been a full member of the Arab Organization for Standardization and ietrology (ASMO). It is also a full member in the Codex Alementarius Cormission (CAC), a Correspondent :lember in the International Organization for Standardization (ISO) and the International Organization for Legal iletrology (OIM).

\section{4) Standardization and Quality Control Project}

In an effort to further promote standardization activities and to ensure the efficient operation of the Directorate of Standards, the Government of Jordan has concluded with the United Nations Industrial Development Organization (INIDO) an arreement to execute jointly a large scale Standardization and Quality Control Project. The ultimate objective of the project is to strengthen standardization and quality control activities in Jordan at the in-plant and national levels with a view to contributing substantially to the improvement of national economy through the efficient use of local raw laterials, reduction of production costs, increased efficiency, raising the quality of locally produced goods, ensuring fairness in trade and commerce, control of imports, promotion of exports and safeguarding the health, safety, and interests of consumers.

The immediate objectives of the project are:

In the field of standards specifications

1. to organize and strengthen the operation of the Directorate of Standards related to the elaboration of national standards;

2. to elaborate and implement a national progran for standardization activities;

3. to bring about the effective application of national standards and to assist in the establishment, organization and operation of standards departments in industrial enterprises.

In the field of quality control

4. to set up, organize and operate industrial testing and quality control laboratories (ITOCL);

5. to organize the proper relationship between the ITOCL and the testing facilities in Jordan;

6. to develop a national quality control scheme with a view to improving the quality of goods and products on the internal and export markets, thereby protecting the consumer and promoting the export trade of Jordan; 
7. to develop quality consciousness among the public and industrial establishments;

8. to organize and operate a national quality certification scheme whereby the standards and quality marks would be granted to products complying to national standards.

In the field of standard weights and measures

9. to establish, organize and operate a Central Standards Laboratory in Amman and District Weights and Measures Offices in the main Governorates of Jordan to accomodate reference standards;

10. to plan, organize and implement national metrolosical services;

11. to effect the smooth transfer to the metric system.

The duration of the project is three and one half years. The execution started, as was previously scheduled, in July 1973, and will be accomplished by the end of 1976 .

The total costs of the project amount to $\$ 1,561,000$. The Government contribution consists of the provision of:
a) Personnel
b) Land and premises (2500 in floor area)
c) Chemicals and glassware
d) Office and laboratory furniture
e) Other operating costs.

The United Nations contribution consists of the provision of:

a) 13 foreign advisors as follows:

1 project manager,

3 experts,

3 associate experts, and 6 consultants

b) 9 fellowships as follows:

1 in organization and administration

of national standardization and quality

control activities,

2 in statistical quality control,

1 in certification marking,

2 in instrumental methods of chemical analysis,

2 in physical and mechanical testing, and

1 in legal metroloy. 
c) Equipment for:

1. Inorganic analysis,

2. Organic analysis,

3. Food analysis,

4. Paint testing,

5. Paper and packaging testins,

6. Leather testing,

7. Textile testing,

8. Metallographic testing,

9. Mechanical testing, and

10. Standardization of welghts and measures

d) Library references

e) Other operating costs

At the end of the project duration (end of 1976) standardization and quality control activities wlll be operated by a Jordanian staff composed of 61 as follows:

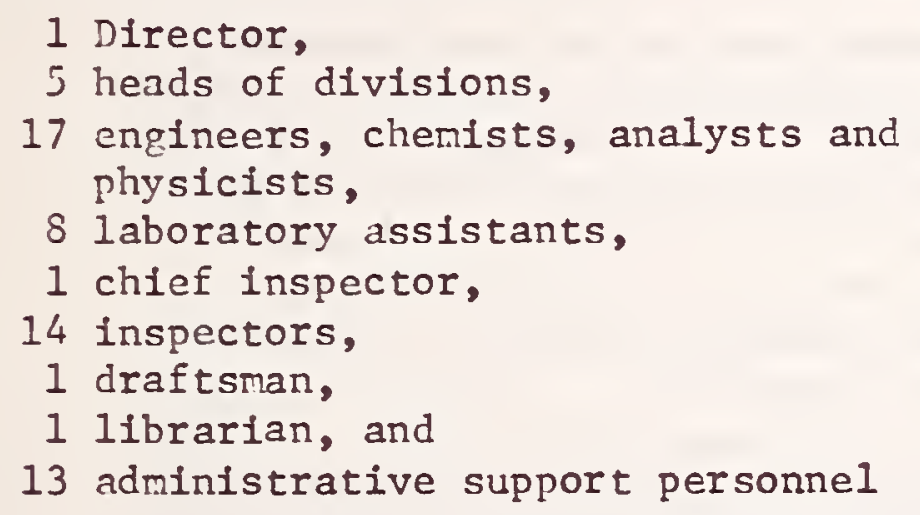


SOME NISRI PROJECTS FOR STREMGTHENING NATION-WIDE TECHNICAL SUPPORT CAPABILITIES OF KOREA'S

NATIONAL RESEARCH \& TESTIIJ ORGAIIIZATIONS

\author{
Mr. Chong Min Lee \\ Chief, Planning Division
}

National Industrial Standards Research Institute

Ministry of Commerce and Industry

Seoul, Republic of Korea

\begin{abstract}
It is my great privilege to be accorded this opportunity of participating in the 1975 NBS/AID Workshop on standardization and Measurement Services in Industrializing Economies. And it is also a great pleasure for me to present some NISRI's projects for strengthening nation-wide technical support capabilities of Korea's national research and testing organizations.
\end{abstract}

To begin with, I would like to briefly introduce the activities of the National Industrial Standards Research Institute.

1) NISRI works for the modernization and establishment of Korea's National Standards System through custody, maintenance and development of the national standards of measurement, testing and inspection services for legal weighing and measurement devices, calibration services for measuring and welghing devices, and establishment of Korea Standards Research Institute which will be explained later.

2) NISRI works for quality control of industrial products through testing and analysis of domestic industrial product either requested by manufacturers or consumers and by government agencies for Korean industrial standard's (KS) quality guarantee testing under the Quality Control Law, and the Industrial Standardization Law, and through testing and analysis of export goods, and production and distribution of standard reference materials.

3) NISRI conducts $R$ \& D work for standardization technology and heat economy for energy conservation such as improvement of Korean traditional heating system, "On-dol" and improvement of efficiency of 19 hole briquet combustion devices.

4) NISRI conducts technical extension services and technical training for the production engineers as well as quality control engineers. 
5) NISRI plans to strengthen the nation's technical support capabilities of existing national research and testing, organizations by establishing new specific research and testing organizations such as Korea Standards Research Institute, Metallic \& Machinery Testing Center, Electric \& Electronic Testing Center, Petrochemical Products Testing Center and Ceramic Testing Center.

1. Background and Necessities of the Establishment of Five Specific Research and Testing Organizations

Before explainfing the 5 spectfic research and testing organizations, let me introduce you briefly to the background of Korean economic growth and industrial development.

A. Korea owes her high economic growth in recent years to the successful implementation of the first and second five-year economic development plans calling for industrialization. During the first five-year economic development plan period (1962-1966), the economy grew at an average annual rate of 8.3 percent, and during the second five-year development plan period (1967-1971) the nation scored an impressive 11.4 percent average growth rate, laying the groundwork for industrial modernization.

The nation's exports amounted to only $\$ 40$ million in 1961 , but thirteen years later in 1974, they hit $\$ 4.6$ billion, representing more than a 100-fold jump. This phenomenal export growth points to the measurable change in Korean industrial structure resulting from the qualitative and quantitative expansion of industry. In 1963 primary products accounted for 54.3 percent of total exports, but the share dropped to 38 percent in 1974, whereas industrial products became the mainstay of export items. This means that the industrial structure has been highly improved, and other strategic industries directly linked to exports have grown substantially.

Meanwhile, the reorganization of small enterprises, and the construction of Saemaul (New Community Movement) plants in rural areas has cleared the way for the specialization of industries, thereby establishing a functional and harmonized industrial structure in each fleld. 
B. The third five-year economic development plan (1972-1976) outlines "epochal development of the rural economy, and promotion of heavy and chemical industries." The plan calls for an annual average economic growth rate of 8.7 percent, and steady development of strategic industries including heavy and chemical industries. Backed by this strength, the nation's economy is expected to grow at an annual average rate of 11.0 percent during the fourth five-year economic development plan perlod (1977-1981).

The long-term prospects for industrial structure in manufacturing are shown in Table 1 , and Figure 1 .

\section{TABLE 1}

LONG-TERM PROSPECTS FOR INDUSTRIAL STRUCTURE

(Rased on the Production in 1970)

(Unit: \$ Million)

\begin{tabular}{|c|c|c|c|c|c|}
\hline & $1972(\mathrm{~A})$ & $1976(B)$ & $1981(C)$ & $\mathrm{B} / \mathrm{A}$ & $C / A$ \\
\hline $\begin{array}{l}\text { Manufacturing } \\
\text { a) Light Industry } \\
\text { b) Heavy and } \\
\text { Chemical } \\
\text { Industries }\end{array}$ & $\begin{array}{l}4,742 \\
(100) \\
3,074 \\
(64.8) \\
1,668 \\
(35.2)\end{array}$ & $\begin{array}{l}8,882 \\
(100) \\
5,170 \\
(58.2) \\
3,712 \\
(41.8)\end{array}$ & $\begin{array}{c}19,142 \\
(100) \\
9,380 \\
(49.0) \\
9,762 \\
(51.0)\end{array}$ & $\begin{array}{l}1.87 \\
1.68 \\
2.23\end{array}$ & $\begin{array}{l}4.04 \\
3.05 \\
5.86\end{array}$ \\
\hline
\end{tabular}

Note 1): Figures in parenthesis are composition ratios (\%).

Source: "Long-term Prospects of Our Economy" by Economic Planning Board. 


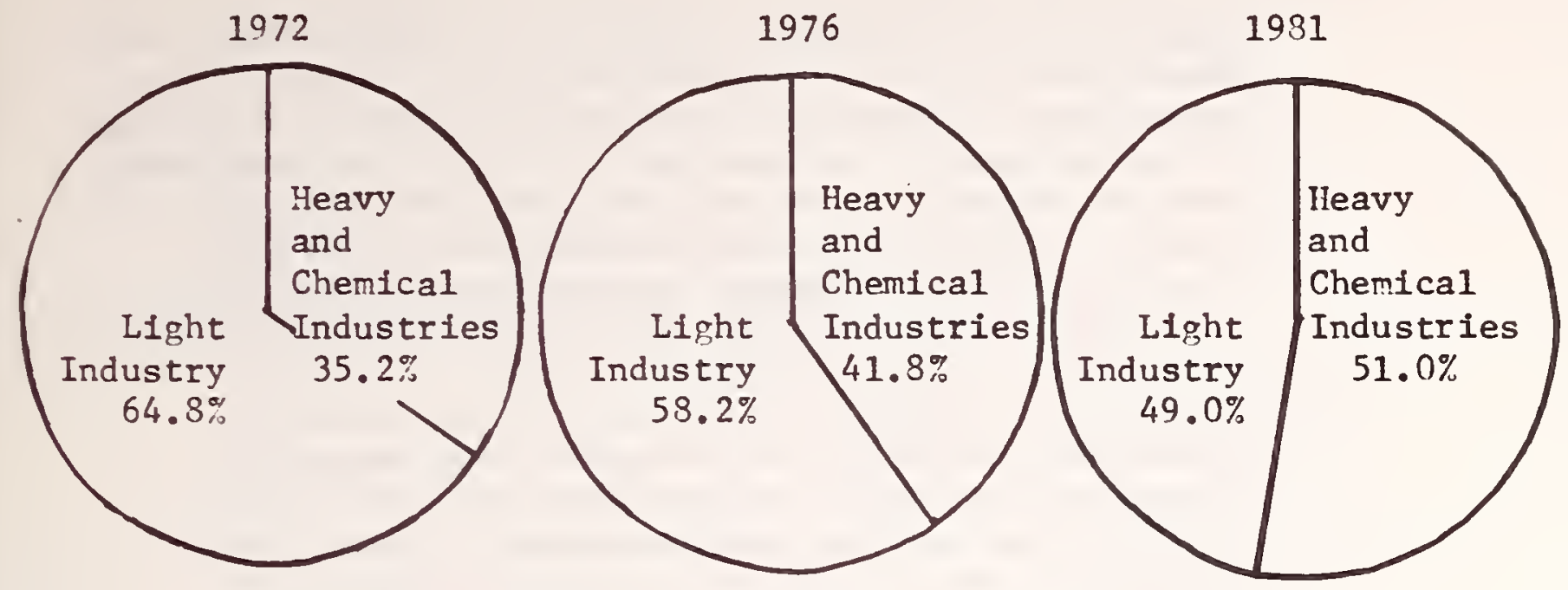

Source: Economic Planning Board

The export target for 1980 is projected to top $\$ 10$ Billion.

These goals cannot be attalned without an epochal development of the export industry. Hence, Korean industry as a whole should be reorganized into a highly technology-intensive industry. In other words, machine, metal and other strategic industries, and petrochemical industries should be further developed to boost exports of the heavy and chemical industrial products.

C. In developing as well as advanced countrles, the import of technology has become an important means of technical development. Importing technology enables developing countries to improve their backward technology, and strengthen their international competitive power. Heanwhile, in Korea, where technological development has been stagnant, foreign technology means technical reform, and provides a driving force for the push for economic development.

D. In Korea where the history of industrial development is short, the development of industry is pushed under government initiatives and the development pattern largely centers on the construction of plants with the inducement of foreign capital and technology, adaptation of advanced foreign technology to local 
conditions, and the establishment of domestic industrial intergration.

Industries in Korea are still poor in technology, and money spent in this field is relatively small. This poses some problems for Korea as the nation is moving into the state of an advanced country. The government has been making steady efforts for technical development and improvement of the quality of industrial products. The Government has been steadily keeping up a campaign for quality control and inspection.

E. In 1967, the Government enacted the Industrial Standards Law in order to improve the quality of industrial products, insure uniformity of quality, improve the convertibility of parts, curtail costs, simplify transactions, and protect consumers.

The Covernment also established the Bureau of Standards, and established the Korean industrial standards (KS) marking system to propagate industrial standards and provide guidance on standards. Under the KS mark authorization system, the Government has been pushing for industrial standardization by disseminating quality control and providing guidance on quality control to industries.

Under the Export Product Inspection Law enacted and promulgated in 1962, the National Industrial Research Institute (NIRI) took charge of matters related to the inspection of export goods, thereby making contributions to quality guarantees for export goods, and improvement of the credibility of exporters on international markets.

In 1961, the Government enacted and promulgated the Weights and Measures Law in order to insure fair trade, and streamline units of measurement. Under the law, the inspection of measuring instruments has been made obligatory, and the legal units of measurement are those of the metric system, while the central bureau of measurement is empowered to handle matters related to inspection and guidance on inspection. However, the organizations responsible for technical development, quality control, and industrial standardization remained scattered among government agencies, causing inefficiency in the execution of 
related affairs. Due to this, the Government revised the Government Organization Law on January 16, 1973, to establish the Industrial Advancement Administration (IAA) under the control of the Ministry of Commerce and Industry, reorganizing or integrating these scattered organizations according to their functions. IAA is responsible for matters related to industrial standardization, quality control; inspection of export goods, protection of consumers, and the development of underground mineral resources.

Meanwhile, NIRI was reorganized into National Industrial Standards Research Institute (NISRI) and placed under IAA control in order to take charge of such extremely important technical matters as the inspection of export goods, test and analysis of industrial products, technical development, the protection of consumers, and the establishment of a national standards system.

In addition, under the control of the Home Ministry are eight provincial industrial inspection laboratories in each administrative zone for the inspection of industrial products in the respective provincial areas. However, as the workload sharply rises in line with the active push for the heavy and chemical industrial development and growing exports, the existing inspection organizations, understaffed and poor in facilities, are today hindered in handling the growling workload. Thus, we are planning to establish 5 specific testing and inspection organizations concerning metrology, metal, machinery, electricity, electronics, petrochemical, fuel, and ceramic fields under an annual program.

F. The testing and inspection organizations, and the major areas of their function are shown in Table 2. of these organizations, eleven are capable of providing testing and inspection for industrial products, including NISRI. 
TESTING, INSPECTION ORGANIZATIONS AND MAJOR FUNCTIONS

\begin{tabular}{|c|c|c|c|}
\hline & Organizations & Function & Location \\
\hline $\begin{array}{l}\text { Run by } \\
\text { Government }\end{array}$ & $\begin{array}{l}\text { National Industrial } \\
\text { Standards Research } \\
\text { Institute }\end{array}$ & $\begin{array}{l}\text { Inspection, research } \\
\text { on chemicals, electric, } \\
\text { machine, metals }\end{array}$ & Seoul \\
\hline & $\begin{array}{l}\text { National } \\
\text { Mneral } \\
\text { Research } \\
\text { Institute }\end{array}$ & $\begin{array}{l}\text { Testing, research on } \\
\text { minerals }\end{array}$ & Seoul \\
\hline & $\begin{array}{l}\text { Provincial } \\
\text { Industrial } \\
\text { Products } \\
\text { Inspection } \\
\text { Laboratory }\end{array}$ & $\begin{array}{l}\text { Inspection of chemi- } \\
\text { cal electrical appli- } \\
\text { ances, machines, metal } \\
\text { products }\end{array}$ & $\begin{array}{l}\text { In each } \\
\text { province }\end{array}$ \\
\hline $\begin{array}{l}\text { Privately } \\
\text { Run }\end{array}$ & $\begin{array}{l}\text { Korean Institute of } \\
\text { Sclence and Technology }\end{array}$ & $\begin{array}{l}\text { Basic research on } \\
\text { chemicals, electricity, } \\
\text { machines, metals }\end{array}$ & Seoul \\
\hline & $\begin{array}{l}\text { Korea Chemical Products } \\
\text { Inspection Foundation }\end{array}$ & $\begin{array}{l}\text { Chemical testing and } \\
\text { inspection }\end{array}$ & Seoul \\
\hline & $\begin{array}{l}\text { Korea General Merchandise } \\
\text { Inspection Foundation }\end{array}$ & $\begin{array}{l}\text { Inspection of knitted } \\
\text { goods }\end{array}$ & $\begin{array}{l}\text { Seoul, } \\
\text { Pusan, } \\
\text { Kyongbuk } \\
\text { province }\end{array}$ \\
\hline & $\begin{array}{l}\text { Korea Fabric Inspection } \\
\text { and Testing Institute } \\
\text { Foundation }\end{array}$ & $\begin{array}{l}\text { Inspection of fiber } \\
\text { products }\end{array}$ & $\begin{array}{l}\text { Seoul, } \\
\text { Pusan, } \\
\text { Kyongnam } \\
\text { province }\end{array}$ \\
\hline & $\begin{array}{l}\text { Korea Package } \\
\text { Inspection } \\
\text { Laboratory }\end{array}$ & $\begin{array}{l}\text { Inspection of } \\
\text { packaging materials }\end{array}$ & Seoul \\
\hline & $\begin{array}{l}\text { Korea General } \\
\text { Merchandise Inspection } \\
\text { Foundation }\end{array}$ & $\begin{array}{l}\text { Inspection of } \\
\text { sundry goods }\end{array}$ & $\begin{array}{l}\text { Seou1, } \\
\text { Pusan, } \\
\text { Kyongbuk } \\
\text { province }\end{array}$ \\
\hline & Fine Instrument Center & $\begin{array}{l}\text { Inspection of } \\
\text { electrical } \\
\text { appliances }\end{array}$ & Seoul \\
\hline
\end{tabular}


2. Korea Standards Research Institute (K-SRI)

Our Government invited the U. S. INS/AID survey teams in 1967, and 1972 as we recognized the seriousness of the inefficient national standards system, since the duties of industrial standardization and ciuality control are scattered over several agencles.

Based upon the iJBS/AID survey team's recommendations, together whth recommendations of G.E. TEXPO which has conducted a study of Korea's iational standards system, we are planning to establish the Korea Standards Research Institute (K-SRI).

Dominant roles of $\mathrm{K}-\mathrm{SRI}$ are to:

1) Yaintain basic units of. measurement

Korea's basic units of measurement are by law those that comprise the SI system of basic, supplementary, and derived units. Prototypes of primary standards of all basic units w111 be acquired and properly maintained by K-SRI and used when required to check national working standards.

2) Maintain international traceability of units

As the Korean representative of CGPM, K-SRI HII periodically compare its prototype standards with international prototypes and with national prototypes of other nations.

3) Assist regulatory agencies

K-SRI w111 serve central and provincial authorities and other organizations in all measurement related matters. Such service can be a legislated requirement or a matter of voluntary cooperation.

\section{$\therefore$ Support laboratories}

Laboratories which offer calibration services to defor.s: forces, industry, universities, and other technical institutions, including weights and measures agencies administering legal metrology, require a central facility where their standards and instruments can be accurately calibrated and certified in terms of traceability to one international source and where their measurement procedures can be verified. 
5) Prepare and/or supply Standard Reference Materials (SPM)

SRM's are used as reference standards in testing, calibrations, analyses, or other industrial controls, assuring, a certain degree of accuracy of results without the need for adopting more complicated or expensive procedures. These SRM's will efther be prepared specially by K-SRI or stockpiled from existing sources of supply to meet user demand.

6) laintain and disseminate up-to-late Standard Reference Data (SRD)

SWD include values of all important physical and chemical constants which affect measurements. K-SRI will collect these, keep them current, and make them avallable to users.

7) Conduct research and development

$R$ \& $D$ on the technology of measurement and calibration is necessary to develop new and better methods of test, and to investigate problems connected with industrial standards and industrial measurement.

3) Offer consulting service and training facilities in metrology

Consulting services on measurements, guidance on apparatus selection, seminars and traininr courses, guest worker programs, textbooks and other publications, and publicity on the objectives of and need for metrology in national Iffe are needed; K-SRI w111 take a leading role in metrology propagation.

9) Disseminate information on metrology

K-SRI will be a central source of the latest information on metrology standards and techniques; it will possess the most authoritative information on the latest research, equipment development, and advances in calibration procedures.

Assigned roles are to:

10) Design, develop, repair, and maintain instruments

K-SRI wIII be staffed and equipped to maintain and repair its own equipment and instruments and will be able to offer repair facilities for instruments to other institutions and users. It will also design and develop highly specialized instruments for which there is demand in Korea. 
11) Offer consulting service on transfer of technology

K-SRI will advise government on technology transfer problems arising from adapting foreign products or problems arising from materials, labor, or instrumentation.

12) Evaluate products, product safety, pollution, and public safety legal letrology

K-SRI's capability in measurement and calibration will be important in evaluating particularly critical products and industrial standardization problems.

For the establishment of K-SRI, an AID loan of 5 million dollars is approved by AID/Washington, and final agreement between the U.S. and the Korean Government was made on September 19, 1975.

As the legal provision has already been made for the establishment of K-SRI by the Enforcement Decree of Specific Research Promotion Law amended and promulgated on August 22, 1975 by Presidential Decree No. 7757, and the Korean endowment fund for operation costs, land purchase will be provided early in October 1975, and the establishment will be realized in October.

Tie are planning to finish building construction, purchase and establishment of laboratory equipment, recruiting staff menbers, and oversee training by the end of 1977. The scale of K-SRI is 11sted in Table 3. 
TABLE 3

SCALE OF K-SRI

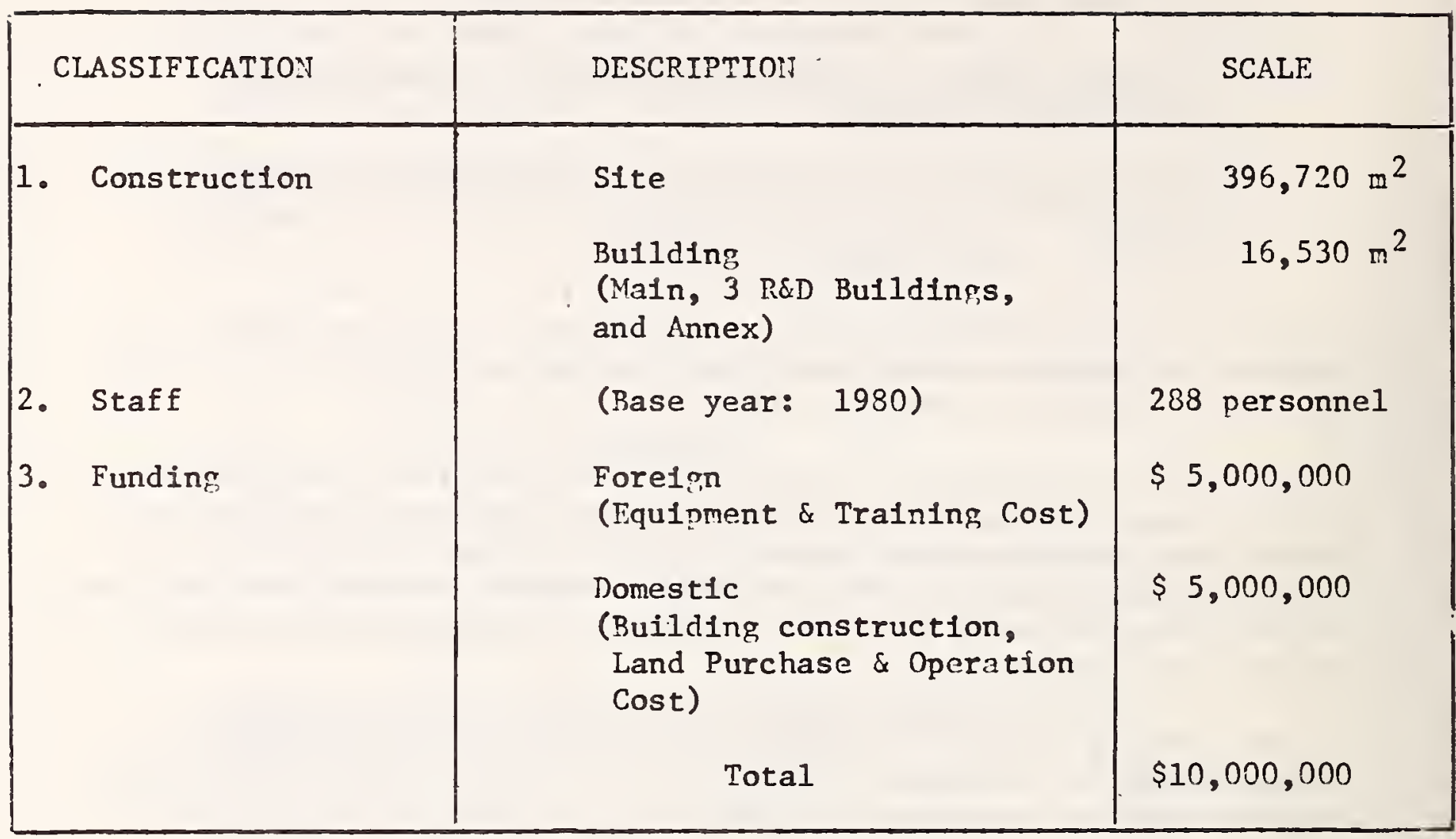

3. Metallic and Machinery Testing Center (MMTC)

The Metallic and Machinery Testing Center will be established for the purpose of technical support to the metallic and machinery industries.

Dominant roles of INTC are to:

1) Test and analyze domestic metallic and machinery products for quality improvement.

2) Conduct export inspection.

3) Offer extension services for quality control of the products.

4) Conduct technical training, for production engineers and Q.C. Inspectors.

5) Disseminate technical information on the metallic and machinery field. 
6) Design and develop metallic and machinery products.

A feasibility study for the establishment of MTTC w111 be conducted by a German consultant team as the fund of 350,000 DM was supported by the Government of West fermany late in 1975.

We are planning to establish IMTC during the period of 1976-1978. The scale of MMTC is shown in Table 4.

TABLE 4

SCALF, OF METALLIC \& MACHINERY TESTING CENTER

\begin{tabular}{|l|l|r|}
\hline CLASSIFICATION & DESCRIPTION & \multicolumn{1}{c|}{ SCALE } \\
\hline 1. Construction & $\begin{array}{l}\text { Site } \\
\text { Building } \\
\text { (Main, 3 R\&D Buildings, } \\
\text { and Annex) }\end{array}$ & $55,000 \mathrm{~m}^{2}$ \\
2. Staff & - & $5,800 \mathrm{~m}^{2}$ \\
3. Funding & $\begin{array}{l}\text { Foreign } \\
\text { (Equipment \& Training Cost) } \\
\text { Domestic } \\
\text { (Building construction, } \\
\text { Land Purchase, \& } \\
\text { Operation Cost) } \\
\text { Total }\end{array}$ & $\$ 2,829,000$ \\
\hline
\end{tabular}

4. Electric \& Electronic Testing Center (EETC)

Electric is Electronlc Testing Center will be established at Ku-li Industrial Estate for the purpose of:

1) Developing of the electric and electronic industry, and improving its products. 
2) Strengthening the nation's international competitive power of the products in its price and quality.

3) Creating a technical extension service.

Dominant roles of EFTC are to:

1) Test domestic electric and electronic products for quality improvement.

2) Conduct export inspection.

3) Offer extension services for quality control of the products.

4) Conduct technical training for production engineers and O.C. inspectors.

5) Disseminate technical information on the electric and electronic field.

6) Design and develop electric and electronic products.

This project was proposed to the Belrium Government for financial assistance in economic cooperation by the Deputy Prime Minister of the Korean Government during his visit to Belrium in July 1975.

We plan to accomplish the establishment of EETC in 1977. The Project Scale is listed in Table 5. 
TABIE 5

SCALE OF ELECTRIC \& ELECTRONIC TESTING CENTER

\begin{tabular}{|l|l|c|}
\hline CLASSIFICATION & EESCRIPTION & SCALE \\
\hline 1. Construction & $\begin{array}{l}\text { Site } \\
\text { Building } \\
\text { (Main, 3 R\&D Buildings } \\
\text { \& Annex) }\end{array}$ & $50,000 \mathrm{~m}^{2}$ \\
2. Staff & - & $5,000 \mathrm{~m}^{2}$ \\
Funding & $\begin{array}{l}\text { Foreirn } \\
\text { (Equipnent \& Training } \\
\text { Cost) } \\
\text { Domestic } \\
\text { (Building construction, } \\
\text { Land Purchase \& } \\
\text { Operation Cost) }\end{array}$ & $\$ 3,736,000$ \\
\hline & Total & $1,909,000$ \\
\hline
\end{tabular}

5. Petrochemica1 Products Testing Center (PPTC)

The petrochemical Products Testing Center will be established at Yo-Su Industrial Estate for the purpose of:

1) Development of the petrochemical industry and improvement of its products.

2) Strengthening the nation's international competitive power in its price and quality.

3) Helping the research and development of petrochemical products.

Dominant role of PPTC is to

1) Test and analyze domestic petrochemical products for quality improvement. 
2) Conduct export inspection.

3) Offer extenston services for quality control of products.

4) Conduct technical training for production engineers and Q.C. inspectors.

5) Disseminate technical information on the petrochemical fleld.

6) Conduct research and development of petrochemical products.

This project was proposed to the French Government for financlal assistance of economic cooperation by the Deputy Prime linister of the Korean Government when he visited France in July 1975. We are planning to begin full operation early in 1980, right after the accomplishment of the building, construction, purchase and establishment of laboratory equipment and technical training. The scale of the project is listed in Table 6.

TABLE 6

SCALE OF PETROCHEMICAL PRODUCTS TESTING CENTER

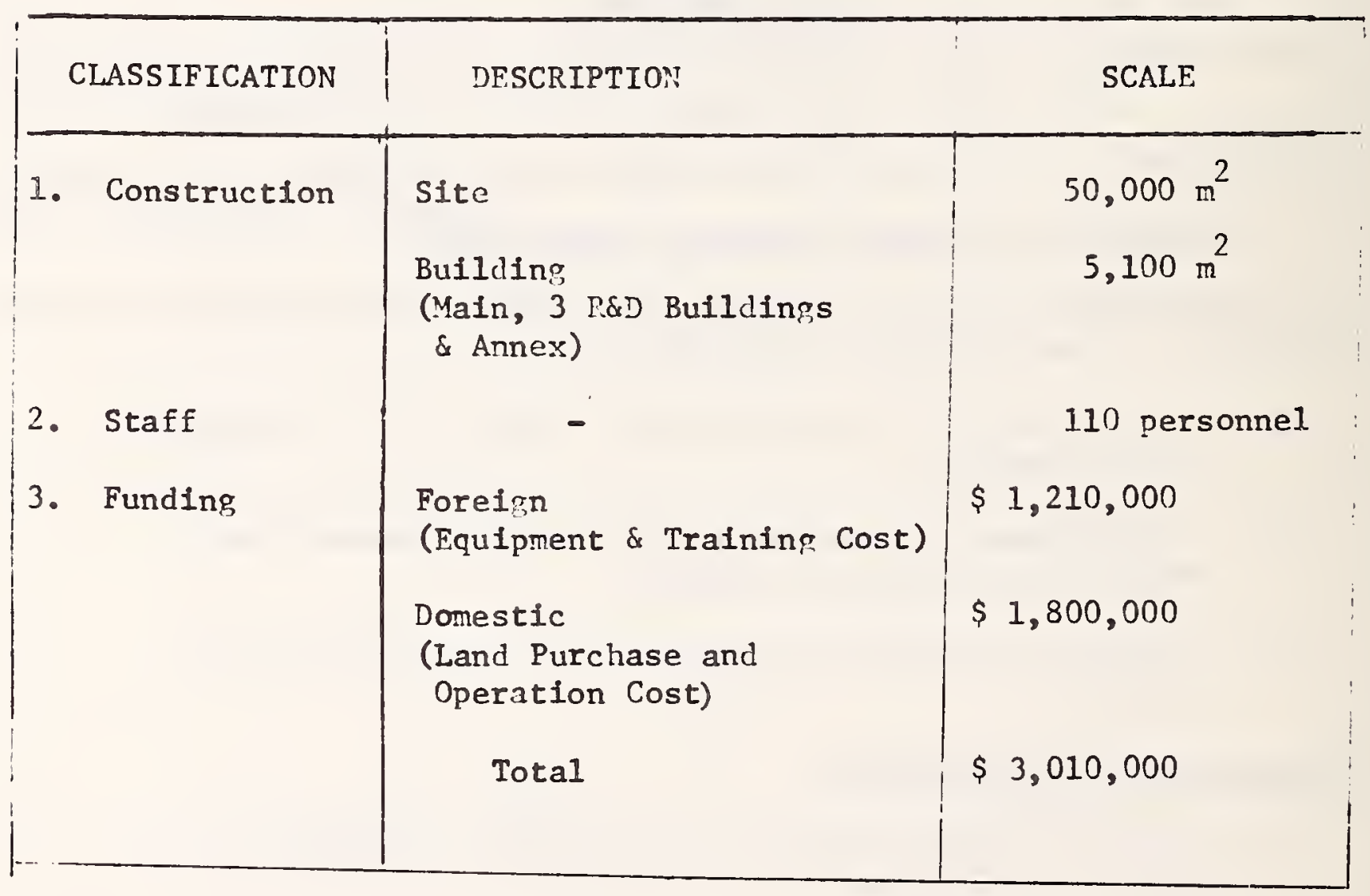


6. Ceramic Testing Center (CTC)

The Ceramic Testing Center is to support development of the ceramic industry through its testing, inspection, and technical extension services in order to help technical improvement of the products and strengthening the nations international competitive power in its price and quality.

Dominant roles of CTC are to:

1) Test and analyze domestic ceramic products for quality improvement.

2) Conduct export inspection.

3) Offer extension services for quality control of the products.

4) Conduct technical training for production encineers and O. C. Inspectors.

5) Disseminate technical information on the ceramic field.

6) Conduct R\&D of ceramic products.

This project was proposed to the Government of England when the Secretary of State for Trade visited l'orea. If the project is successfully supported, the CTC will be in full operation early in 1980. The scale of the project is listed in Table 7. 
SCALE OF CEPAMIC TESTING CENTER

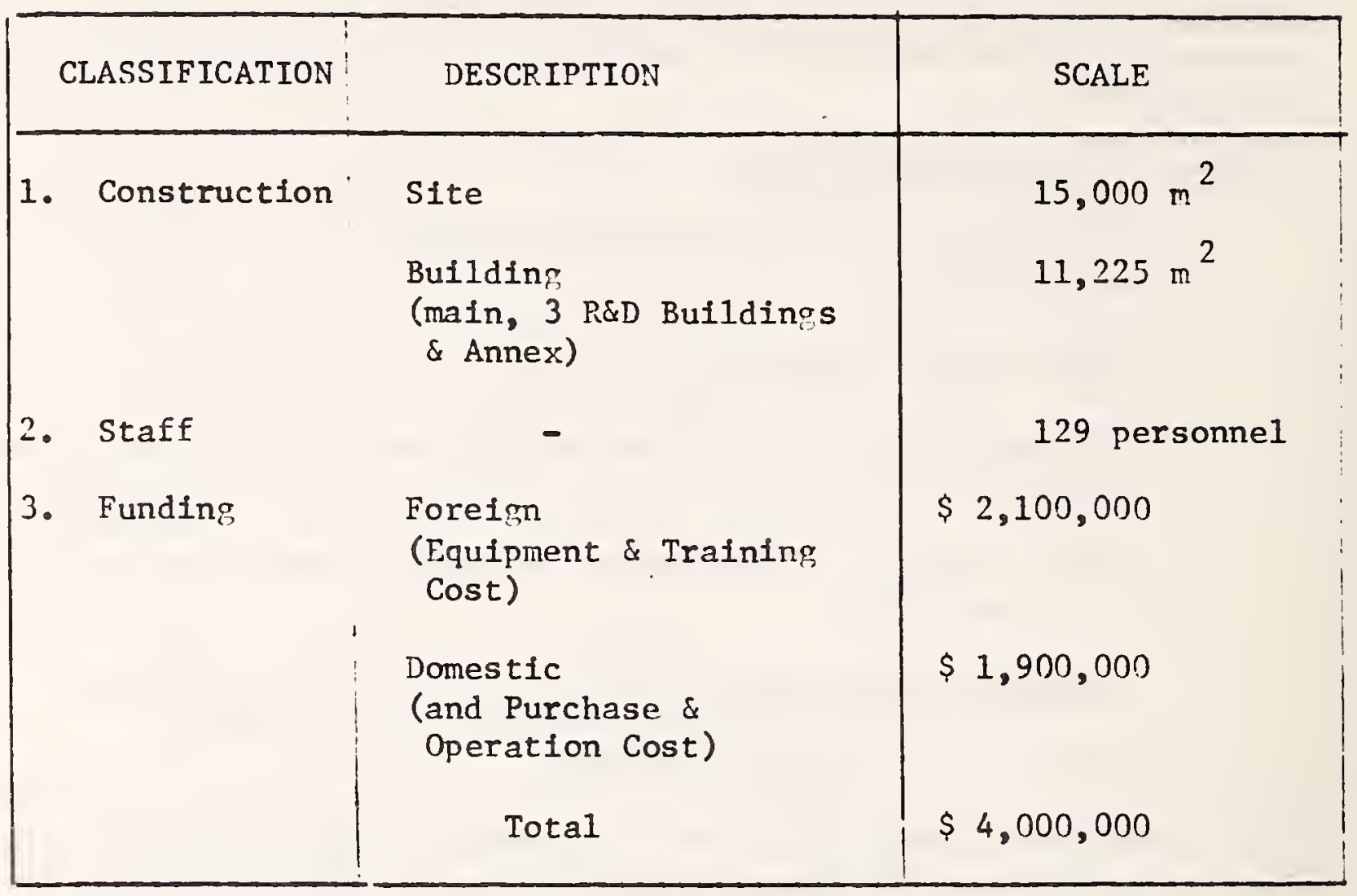

\section{Conclusion}

As I explained to you before, NISRI is planning to establish five specific research and testing organizations in order to strengthen nation-wide technical support capabilities for Korean industries, even though it is very hard work funding and implementing the projects.

I can easily say that our industrial products will be hirhly improved in their quality and competitive power in the international market, if those projects are properly supported. 
Dr. Enrique Guériero L.

Chief, Food and Quality Control Division Ministry of Economy, Industry, and Commerce Managua, Nicaragua

The metric decimal system exists by decree since 1893, but has not been regulated as yet.

In January 1960 Decree No. 465 was issued on measures of volume for coffee and other grains, as follows:

1 "fanega" - 1 bag - 24 halves

1 half

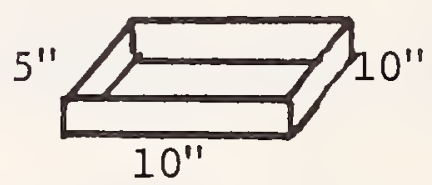

Ten inches per side and five inches high

1 fourth

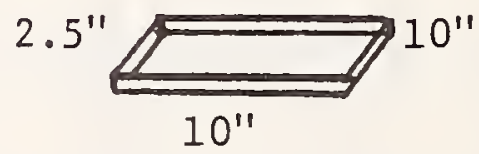

Similar to above square but two and a half inches high

Diversity of Weights and Measures

Speaking of Weight: We have metric tons, Spanish and English pounds, ounces, and grams.

Speaking of Volume: We have cubic meters, imperial gallons, bottles, and fluid ounces.

Speaking of Surface: We have kilometers, miles, meters, yards, "varas", blocks, and leagues.

Termperature is in Centigrade and Farenheit, boilers in pounds of pressure per square inch. 
Since we are members of the Central American Common liarlect and belon? to several development institutions, in August 1975 we established a Standards and nuality Control Committee consistine of:
a) the General Trade Bureau of the Ministry of Economy,
b) the Technological Research lepartment of the Central Bank,
c) the :inistry of Agriculture and Livestock,
d) the Chamber of Industries, and
e) the Iational Development Institute,

With the purpose of:

1) regulating weights and measures,

2) standardizing with ICAITI (Central American Industrial Technology and Research Institute) and COPAitT (Pan American Technical Standards Comission),

3) controlling product quality, and

4) Issuine the Fond products Labelins Act.

I'e have requested technical assistance from ICATTT to start our work. Some Functions of Develonment Ministries and Institutions

1) Ministry of Economy, Industry, and Trade, General Bureau of Commerce

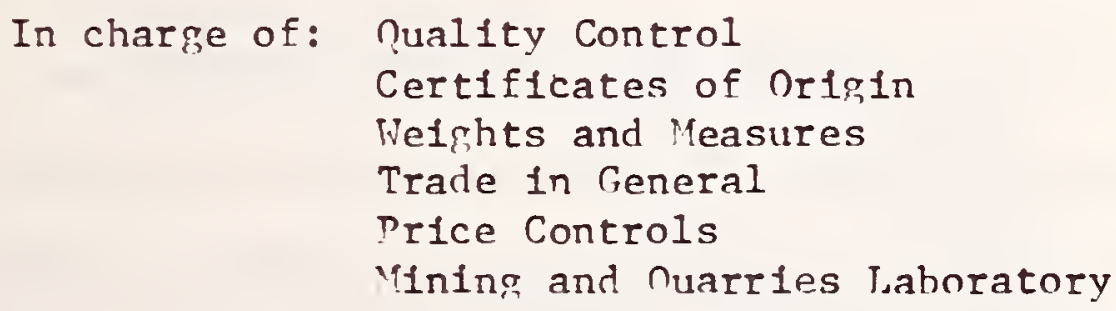

2) Iinistry of Public Health

Drus and Food Control

Cosmetics Control

Weights and "leasures

Analysis Lahoratory 
3) :Inistry of Arriculture and Livestoc:
Animal Ilealth Certificates
Control of Slaughterhouses
Import and Txport of Feed rrains
Analysis I.aboratory

4) 'inistry of the National District

$$
\begin{aligned}
& \text { Inns and Markets Act } \\
& \text { Welphts and 'easures Control }
\end{aligned}
$$

5) Iinistry of Development and Public Vorlss

$$
\begin{aligned}
& \text { 'aterials Streneth Taboratory } \\
& \text { If hhay Load Control }
\end{aligned}
$$

6) Central Bank

Food Technolory Laboratory

7) National Autonomous Iniversity of Nicaragua

$$
\text { Analysis Laboratory }
$$

8) Central American University

$$
\text { Analysis Laboratory }
$$

9) Vatfonal Development Institute

$$
\text { Agro-industrial Development Prorrams }
$$

10) Ministry of Labor

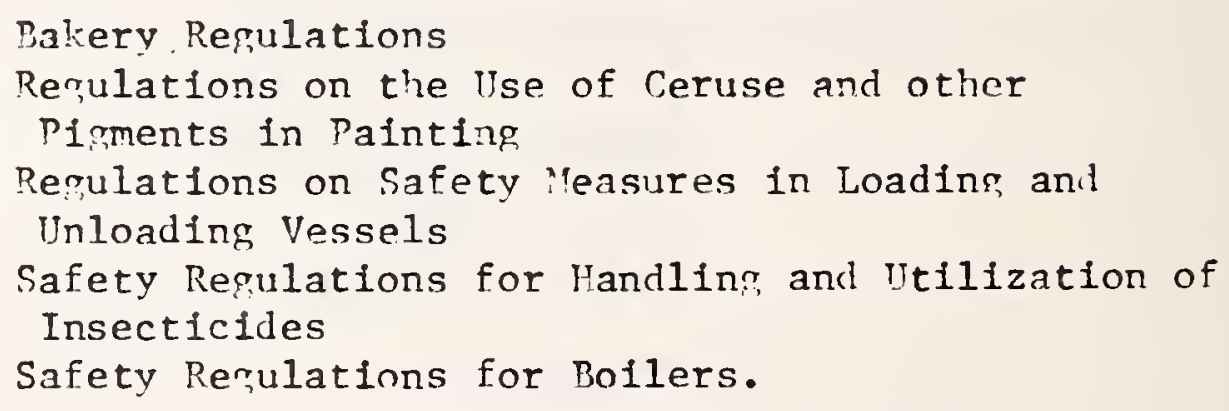




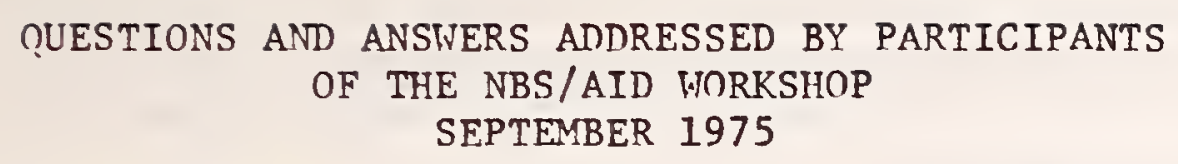

Ouestion:

A. RELEVANCE TO YOUR PROGRAMS IN YOUR COUNTRY

1. IHAT FRACTION OF THE PRESENTATIONS HAD ANY RELEVANCE TO YOUR
a. PRESENT NEEDS?
b. FUTURE NEEDS (AS SFEN BY YOU NOW)?

Answers:

a. PRESENT NEEDS ?

Ing. Hugo BRANGIER: We can Indicate subjects related to:

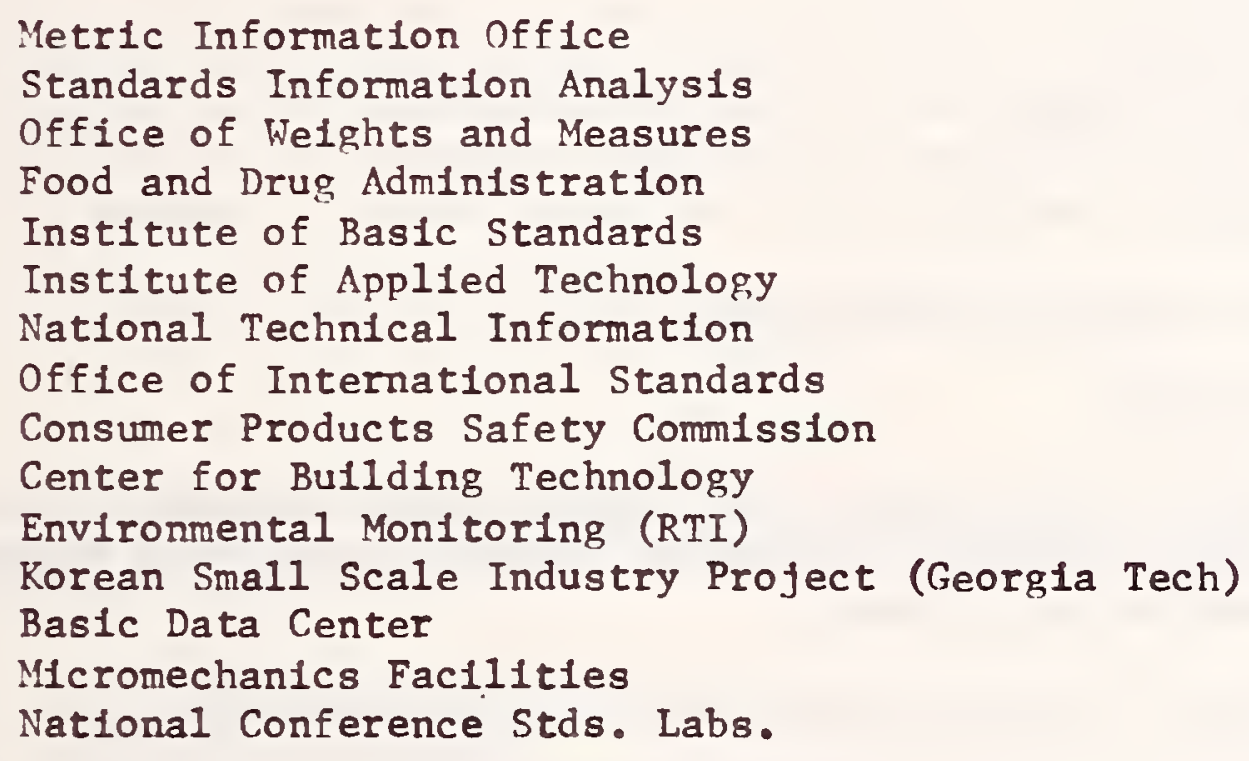

Dr. Anwar EL-TAWIL: Almost all presentations were relevant.

Mr. LEE, Chung Min: Presentations at NBS were mostly relevant to both present and future needs.

b. FUTURE NEEDS (AS SEEN BY YOU NOW)?

BRANGIER: Metrology problems presentation.

Mr. Jorge Enrlque BARRIOS: The presentations of Mr. Bud Wollin from the Office of Welghts and Measures and Mr. H. A. Fowler from the Institute for Basic Standards.

EL-TAWIL: Almost all presentations were relevant. 
Question:

2. WHICH PRESENTATIONS COULD HAVE BEEN OMITTED
a. IN GAITHERSBURG?
b. IN BOULDER?
c. ELSEWHERE?

\section{Answers:}

a. IN GAITHERSBURG?

Tag Mohammad YARMAND: None

BRANGIER: International Geology, Cumputer Sciences and Technology, Data Systems Design.

BARRIOS: The visits to the Atomic Reactor, to the Institute for Computer Sciences and Technology, and to the Data System Design Laboratory, because they implicated a very high technology.

b. IN BOULDER?

YARMAND: None.

BRANGIER: None.

LEE: Nothing in particular.

c. ELSEWIIERE?

BARRIOS: The visits to IBM and Burroughs Wellcome at the Research Trlangle Institute and the visit to the University of Texas at San Antonlo.

EL-TAWIL: The IBM visit since it was too brlef.

\section{Question:}

3. WHICH PRESENTATIONS WERE TOO BRIEF
a. IN GAITHERSBURG?
b. IN BOULDER?
c. ELSEWHERE?

\section{Answers:}

YARMAND: The presentations of some participants of our group were too brief.

BARRIOS: Mr. Bud Wollin's presentation. 
EL-TAWIL: All presentations were rather brlef. I suggest that the number of all subjects be reduced and the lecturers given more time to develop their themes and complement them with tours and practical demonstrations.

LEE: Nothing particularly anywhere.

b. IN BOULDER?

BARRIOS: Mr. H. L. Daneman's presentation.

c. ELSETHERE?

YARMAND: None.

Question:

4. WHAT PRESENTATIONS SHOULD HAVE BEEN ADDED?

Answers:

BARRIOS: The ones related to practical methods to establish a rational Welghts and Measures System and 1ts adequate control mechanisms in a developing country, as well as the possible solutions to the problems owing to the implantation of that system, based on the U.S.A. experience.

LEE: A more intensive NBS tour should preferably have been made.

Nuestion:

5. DID YOU APPRECIATE THE PRESENTATIONS FROM OTHER PARTICIPANTS TO SUCH AN EXTENT THAT YOU WISH MORE TIME SHOULD HAVE BEEN DEVOTED TO THEM

a. BY LONGER SESSIONS?

b. ADDITIONAL SESSIONS?

c. REDUCTION OF OTHER PRESENTATIONS?

\begin{tabular}{|c|c|c|c|c|}
\hline YARMAND: & BRANGIER: & BARRIOS: & EL-TAWIL: & LFE: \\
\hline a-Yes & a & $a-N_{0}$ & a-Yes & \\
\hline b & b & b-Yes & b-Yes & $b$-Yes \\
\hline c & c & $c-N_{0}$ & c & c \\
\hline
\end{tabular}


B. OUALITY OF PRESENTATIONS AND NBS/AID PROGRAMS

1. WHICH PRESENTATION WAS THE BEST FOR YOU
a. IN GAITHERSBURG?
b. IN BOULDER?
c. ELSEWHERE?

\section{Answers:}

a. IN GAITHERSBURG?

YARMAND: For me, all were Interesting and useful.

BRANGIER: Office of Weights and Measures, Food and Drug Administration, Institute for Basic Standards, Institute for Applied Technology.

BARRIOS: Mr. Charles B. Phucas's presentation.

b. IN BOULDER?

BRANGIER: Mr. Daneman's presentation: "Planning of Standards Laboratories in Developing Countries."

BARRIOS: Mr. H. L. Daneman's presentation.

c. ELSEWHERE?

BRANGIER: The Institute of Small Industry of the Philippines, presented by Mrs. Herminia Rosales-Fajardo.

\section{Question:}

2. DO YOU PLAN IN FUTURE

a. TO REQUEST NBS LITERATURE?

b. TO REQUEST U.S. STANDARDS LITERATURE?

c. TO REQUEST SRM' $s$ ?

d. A GUEST WORKER STAY AT NBS FOR YOURSELF?

e. A GUEST WORKER STAY AT NBS FOR OTHERS?

f. TO SUGGEST TO YOUR GOVERNMENT TO INVITE A SURVEY?

g. TO SUGGEST TO YOUR GOVERMMENT TO SEEK TO SFND TRAINEES?

h. TO RECOMMEND THAT OTHERS FROM YOUR COUNTRY GO TO NBS/AID WORKSHOPS?

i. TO RECOMMEND THAT OTHERS FROM OTHER COUNTRIES GO TO NBS/AID WORKSHOPS?

j. TO RECOMMEND THAT YOUR COUNTRY HOST A REGIONAL SEMINAR? 


\begin{tabular}{|c|c|c|c|c|}
\hline YARMAND: & BRANGIER: & BARRIOS: & EL-TAWIL: & LEE: \\
\hline a-Yes & a-Yes & a-Yes & a-Yes & a-Yes \\
\hline b-Yes & b-Yes & $b$ & b-Yes & b-Yes \\
\hline c-Yes & $c-\mathrm{No}$ & $c-N_{0}$ & c-possibly & c \\
\hline d & $d$-No & $\mathrm{d}-\mathrm{No}$ & d & d-yes \\
\hline e & $e-N o$ & e-Yes & e-possibly & e \\
\hline $\mathrm{f}$ & $f-N_{0}$ & f-Yes & f-Yes & $\mathrm{f}$ \\
\hline$g$ & g-probably & $\begin{array}{l}\text { g-Yes } \\
\text { h-Yes }\end{array}$ & $\begin{array}{l}\text { g-Yes } \\
\text { h-Yes }\end{array}$ & g-Yes \\
\hline 1 & 1-probably & 1 -No & 1 & 1-Yes \\
\hline j & $j-$ No & $j-$ No & $j-\mathrm{No}$ & j-Yes \\
\hline
\end{tabular}

\section{Question:}

3. WHAT SUGGESTIONS WOULD YOU MAKE FOR THE ORGANIZATIONAL ARRANGEMENTS FOR NRS/AID WORKSHOPS?

\section{Answers:}

YARMAND: In my opinion, the NBS/AID program was very we11 organized.

BRANGIER: That previous communications should be sent well in advance and detailed programs should be circulated so as to determine its usefulness before deciding to attend.

BARRIOS: The program should have been sent more days in advance. The candidates should be selected according to their activities in order to prevent a heterogeneous group.

The fractions of the presentations related to standardization and Metrology should be set apart and planned in a suitable form.

The program was very intense to fulf111 during the planned time.

There were many visits to special laboratories that use a very high technology.

More time should have been devoted to the visits made to documentation centers.

The visits to the different laboratories should have been well coordinated in order to avold improvisation (for instance, the visit to a laboratory under construction at Texas University in San Antonio).

EL-TAWIL: The organization was excellent, but I would suggest adopting a less tight schedule with fewer subjects and more concentration on each subject. The same goes for the travel where at least one place could be sklpped. I think the hired bus arrangement would be more convenlent than alr travel, at least partially.

LEE: Your organizational arrangements were so perfect that no other suggestions are needed. 
C. PERSONAL QUESTIONS

1. DID YOU (a) ENJOY THE NBS/AID WORKSHOP?

(b) REGRET ATTENDING THE NBS/AID WORKSHOP?

\section{Answers:}

a. ENJOY THE NBS/AID WORKSHOP?

YARMAND: Yes.

BRANGIER: I enfoyed the workshop very much and I highly appreclated the opportunity to attend $1 t$.

BARRIOS: Yes.

EL-TAWIL: Yes.

LEE: I really enjoyed the NBS/AID Workshop.

Question:

2. DID YOU PROFIT PROFESSIONALLY IN SOME WAY?

\section{Answers:}

YARMAND: From this program I galned lots of experiences which are useful for good organization of activities of norms and standards in Afghanistan.

BRANGIER: Yes, In many ways, especlally through the contacts we made.

BARRIOS: In general, it was a very interesting personal and professional experience, but due to the short time we only had the opportunity to.get a general view of U.S. work in that fleld. I wish we had had more time to emphasize some aspects and to Interchange Ideas and experiences with the other participants.

EL-TAWIL: Yes, In many ways.

LEE: Yes.

Question:

3. DO YOU FEEL YOU HAVE ESTABLISHED PERSONAL AND USEFUL CONTACTS

a. WITH NBS STAFF?

b. OTHER U.S. COLLEAGUES?

c. WITH OTHER WORKSHOP PARTICIPANTS? 


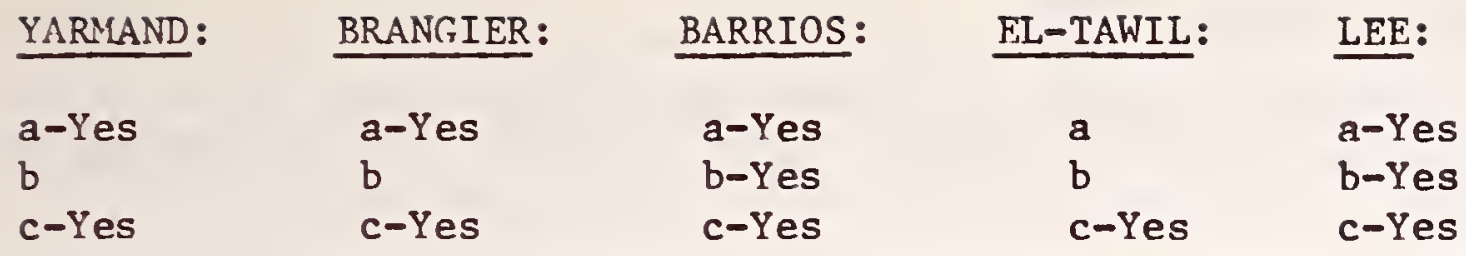

Nuestion:

4. DO YOU FEEL YOUR COUNTRY SHOULD HAVE SENT SOMEONE ELSE OF

a. GRFATER SENIORITY (IN JOB)?

b. LESSER SENIORITY (IN JOB)?

c. GREATER TECHNICAL EXPERIENCE?

d. LESSER TECHNICAL EXPERIENCE?

\begin{tabular}{|c|c|c|c|}
\hline YARMAND: & BRANGIER: & BARRIOS: & EL-TAWIL: \\
\hline a-Yes & a & a-Yes & a \\
\hline b & b-Yes & b-No & b \\
\hline c-Yes & c & c-Yes & c \\
\hline$d$ & d & $d-N o$ & $d$ \\
\hline
\end{tabular}

\section{Question:}

D. ANY OTHER RERIARKS

YARMAND: I am thankful to Mr. Pelser and all his assoclates for giving frultful speeches and more information at NBS as well as at the NCSL Workshop.

EL-TAWIL: I should like to thank the organizers of the Workshop for their untiring efforts to make everything fine for the particlpants. The dedication of Steffen Pelser and the kindness of Chris Raley have impressed me deeply.

Thank you! 
"The experience and information achieved has proved to be outstandingly useful in our related field of weights and measures in order to make it applicable and adapted to our possibilities.

"I encourage the NBS authorities to continue this program of activities that enables the developing countries to be informed on the advances made by your institution, one of the most important of America in technology.

"The only observation, if any, and in attendance of the questionnaire mentioned before our departure, is to consider separate programs in relation to the different interests involved: for instance, those participants mainly interested in standardization or those in computer sciences, or those specifically in technical specialized laboratories. In all the other aspects everything has been perfectly organized, directed, and supervised. My sincere conpratulations to Dr. F. Brady and to you!"

Mr. Ricardo FLOREZ:

"First of all, I want to thank $\mathrm{H}$. Steffen Peiser very much for having included me in the 1975 NBS/AID Workshop. I would also like to thank Steffen and the colleagues of his office for the two weeks of extra work they have been through on top of all the preparations so we could make the best use of the available time and opportunities. I would like to thank Chris Raley for all his attention and patience, Joanne and Joan for taking care of me and Mrs. Bullman, Cathy, and Doris for all their kindness. The biggest thanks of all goes to steffen and his incredible energy in handling the workshop activities and trips and still finding many hours in his busy days to help a privileged Brazilian put together his reports in English.

"Working, with the National Bureau of Standards for 8 months already by the time of the workshop, it was for me an opportunity to review what I had seen and be aware of many things I still have to learn.

"I am also sending you some personal comments on the workshop, hoping they may be of some use to you when planning the future ones."

A - Relevance to IPT in Brazil

"Measurement services and standardization are the main tools, together with personnel training, with which IPT performs its assigned tasks to government and industry, improving technology and science in the State of Sao Paulo and therefore in Brazil. 
"Contacts with forelgn activities in these flelds are of extreme importance to IPT. We have to learn fast and operate under the constraints of a developing economy, improving quality and reliability of our work at the same time.

"The opportunity to be exposed to a cross section of the standard and measurement activities in the U.S., and at the same time be in touch with colleagues from various countries, discussing related common problems and goals, has been timely and priceless for me, my institute, and my country."

\section{B - The Program}

"The selected presentations and visits vere very rood without exception, even though some of them were a little far from the immediate. IPT scope of activities and ny own technical expertise, to be fully evaluated.

"The presentations at ins covered almost all asoects of the standards cormunity activities, the National Conference of Standards Laboratories being a good complement to that, and the institutes and industries visited a rood sample of its users.

"The type of vorlsshop provided excelient opportunities for institutes from other countries to get in contact with their counterparts in the United States, and share opinions on ongolng activities.

"For some this may be the very first sten towards a collaborative promram with U.S. Institutes, and for othors, as is the case of IPT, a comblenent of the ongoing programs.

"The visits to the Research Trianrle, and the Southrest Research Inst1tute, were for me very productive. I could draw from those visits a much better understanding of the roles and opportunities of those institutes, and their organization in order to be able to compare then to JPT's."

\section{C - Contact with the Other Participants}

"This was an imnortant aspect of the workshop for me. The opportunity to discuss with my collearues from Egypt and Korea some of our countries' common issues was unique. The presentation of individual papers addressing standardization and measurement services on each of the represented countries set the basis for those discussions.

"I hope this person to person contact develops into a less formal and more meaningful relation between our countries, through our institutes. 
"Being new in the international relations activities of my institute, and in its name representing my country, Brazil, in the NBS/AID Torkshop, was a revarding professional experience. I hope my general lack of experience and small technical expertise in some areas didn't compromise my participation in the workshop. On the other hand, when the discussions were close to the areas covered by the IPT/NPS program, I felt quite at home. The benefits to the IPT/NBS program were bis as far as I am concerned and this certainly will add up to improvement in the way I will be performing my tasks from now on. This way, my experiences will be shared with my colleagues in Sao Paulo for the benefit of my country, and the workshop will have served its purpose." 


\section{APPFNDIX II}

WORKSYOP PARTICIPANTS AW BIOGRAPHICAL DATA

:Ir. Taj Yohammad Yarmand

General Director

Viorms and Standards Denartment

"inistry of "ines and Industries

Kabul, Afghanistan

Yr. Yarmand, born Octoher 12, 1935, in Kabul, Afghanistan, received a ifaster of Science degree in Mecanical Engineering from the Polytechnical Institute in the U.S.S.R. He is presently General Director of the Yorms and Standards Department of the Ministry of Yines and Industries in Kabul, Afghanistan.

'ir. Ricardo Tlorez

Architect

Tecinological Research Institute

Sao Paulo, Brazil

Yir. Florez, born October 30, 1943, in Santos, Brazil, received his degree in architecture from the University of Sao Paulo in 1969. He is entered in the "lasters Program majoring in Urban design. Mr. Florez is presently helping to coordinate a collaborative program hetween the National Bureau of Standards and the State Council for Technology, Sao Paulo, Brazil.

Dr. llugo Brangier $\%$.

Executive Director

National Institute of Standards

Santiago, Chile

Dr. Brangier, born May 29, 1923, in Talcahuano, Chile, received a science degree in Chemistry from the University of Concepcion in Chile. Dr. Brangier participated in the NBS/AID Workshop as Executive Director of the Vational Standardization Institute in Santiago, Chile. 
Mr. Jorge Enrique Barrios

Chief, Chemical Division

Colombian Institute of Technical Standards (ICONTEC)

Rogota, Colombia

Mr. Barrios, born January 30, 1948, in Ibague, Colombia, received his engineering degree in Agronomy. He is presently Chief of the Chemistry Division of the Colombian Institute of Technical Standards in Bogota, Colombia.

Dr. Josefina Espaillat Duran

Under-Secretary of State for Industry and Commerce lead, Standardization and Quality Control Department Santo Domingo, Dorinican Republic

Dr. Duran, born Anril 3, 1938, in Santo Domingo, Dominican Republic, received a Ph.D. in Law from the University of Santo Domingo in 1960. )r. Duran is presently Under-Secretary of State for Industry and Comerce and is in charge of the Standardization and nulity control Department, Santo Domingo, Dominican Republic.

Dr. Anwar El-Tawil

Chief, Industrial "qetrology Division

Eryptian Organization for Standardization

Cairo, Egypt

Dr. E1-Tawil, born Anril 3, 1939, in Kaltoubia, Egypt, received a Pachelor of Science degree in Yechanical Engineering, in 1959 and a Ph.D. In Metrology from the Faculty of Machine, Tools and Instruments, Hoscow, U.S.S.R. in 1965. He is presently Chief of the Industrial Metrology Division of the Epyptain Orranization for Standardization in Cairo, Egypt.

Mr. Abder Rahman El-Keilani

llead, Weights and Neasurement Section

Directorate of Standards and Metrology

Ministry of Industry and Trade

Amman, Jordan

Mr. E1-Keilani, born In 1947, in Vablus, Jaffa, received a R.S. degree from Alm Shama University in 1971 havins mafored in Chemistry and

Geology. He is presently Head of the Scales and Weight Section of the Specifications and Measures Mirectorate of the :linistry of Industry and Commerce in Amman, Jordan. 
Mr. Chong-Min Lee

Chief, Plannins Division

National Industrial Standards Research Institute

'Inistry of Commerce and Industry

Seoul, Korea

:Ir. Lee, born May 3, 1936, in Kyung-K1-Do Province, Korea, received a B.A. and graduate degrees in Chemical Enoineering from Hanyang University and has studied Ceramics Encineering at the graduate schools of the University of Missourl and Pennsylvania State. Mr. Lee is presently Chief of the Planning Division of the National Industrial Standards Research Institute In Seoul, Republic of Korea.

Dr. Enrique Cruerrero L.

Chief, Food and Nuality Control Division

:inistry of Fconomy, Intustry and Commerce

Mianagua, iilcaragua

Dr. Guerrero, born July 15, 1322, in Granada, Nicaragua, recelved his desree in Chemistry and Pharmacy from the vational University of iicaragua in 1955 and a certificate from Technion, Israel, for studies in 1969. Dr. Guerrero is presently Chief of the Food and nuality Control Division of the Ministry of Economy, Industry and Commerce in :lanagua, Iicaragua. 
